\title{
Indicators of hot fluid migration in sedimentary basins: evidence from the UK Atlantic Margin
}

\author{
H. L. Wycherley ${ }^{1}$, J. Parnell ${ }^{1}$, G. R. Watt ${ }^{1}$, H. Chen $^{1}$ and A. J. Boyce ${ }^{2}$ \\ ${ }^{1}$ Geofluids Research Group, Department of Geology \& Petroleum Geology, University of Aberdeen, Aberdeen AB24 $3 U E$, \\ UK (e-mail: h.wycherley@abdn.ac.uk) \\ ${ }^{2}$ Scottish Universities Environmental Research Centre (SUERC), Scottish Enterprise Technology Park, Rankine Avenue, \\ Glasgow G75 OQF, UK
}

\begin{abstract}
Microthermometric, petrographic and isotopic methods have been used to detect evidence for hot fluid flow in Mesozoic and Tertiary sediments from the NW UK continental margin, West of Shetland. New data presented here show that temperatures are hotter by $c .40^{\circ} \mathrm{C}$ in Tertiary samples than in the underlying Jurassic and Cretaceous sediments in wells 204/28-1, 206/5-2, 208/27-1, especially in cements from samples as young as mid-upper Eocene in age. Paleocene samples can be discriminated from older (Jurassic and Cretaceous) and younger (Eocene) sandstones on the basis of silica cement morphology and cathodoluminescence zonation. Jurassic, Cretaceous and Eocene quartz cements show oscillatory zoning as a consequence of relatively slow burial cementation. In direct contrast, rapid precipitation of silica cements from the cooling of hot fluids has produced unzoned cements in all but one Paleocene sample. No evidence for unzoned quartz cements was noted in any pre-Paleocene or Eocene samples. The restriction of hot fluid inclusions and unzoned cements to the Paleocene and post-Paleocene is consistent with lateral focusing of hot fluids. Isotopic data from kaolinites indicate that these fluids are best represented by mixtures of Mesozoic or Tertiary meteoric waters and marine porewaters that have undergone isotopic alteration through interaction with volcanic material. Our results indicate that hot fluid flow occurred over a relatively long time-scale (i.e. several million years), which may have important consequences for the degradation of reservoired hydrocarbons in West of Shetland Paleocene plays.
\end{abstract}

KEYWORDS: West of Shetland, Tertiary, cements, quartz, zoning, palaeotemperature

\section{INTRODUCTION}

Transient hot fluid flow events such as those connected to rift-related volcanic activity can impact all aspects of the hydrocarbon industry, from enhanced source rock maturity to reservoir degradation by rapid cementation from cooling fluids. A full understanding of fluid migration pathways, thermal history and diagenetic processes related to hot fluid migration is, therefore, extremely important in the effective development of hydrocarbon provinces in ocean margin settings. At least two major episodes of hot fluid migration have been recognized on the NW UK Atlantic Margin - a Late Jurassic-Early Cretaceous rift-related pulse and a Tertiary event ascribed to magmatic activity (Nadin et al. 1997; Clift 1999; Dean et al. 1999; Naylor et al. 1999; Parnell et al. 1999). Apatite fission track analyses (AFTA), vitrinite reflectance and fluid inclusion microthermometry have shown that these hot fluid pulses involved fluids which record palaeotemperatures up to $200^{\circ} \mathrm{C}$ (Green et al. 1999; Parnell et al. 1999) which indicates rapid emplacement. Fluids trapped as inclusions during flow were thus significantly hotter than predicted from burial histories, and recorded temperatures much hotter than those represented by vitrinite reflectance data (Parnell et al. 2001). However, we use the term 'hot fluid' to refer to fluids that are represented by fluid inclusion homogenization temperatures which are at least $20^{\circ} \mathrm{C}$ higher than the maximum temperature attributable to burial.

In this paper the aim is to identify petrographic and geochemical features of samples which may have undergone hot fluid migration related to Tertiary magmatic activity, and assess the distribution of these features with respect to published models for hot fluid flow West of Shetland (WOS). The large volumes of igneous material emplaced during this event appear to have had no regional-scale effect on geothermal gradients (Holmes et al. 1999), but localized effects are both predicted (Turner \& Scrutton 1993) and observed (Parnell et al. 1999). Hot fluid migration may produce several recordable features in rocks, including the alteration of matrix and cement phases and the deposition of new minerals during cooling (which, in turn, may trap syn-flow fluids). Discrimination of short-lived hot fluid pulses from basin-wide burial heating effects and detection of the pathways along which fluids have migrated, requires identification of localized hot fluid petrographic and geochemical effects. A number of features were investigated: 
1. stratigraphically restricted features (e.g. anomolously hightemperature fluid inclusions restricted to certain stratigraphic levels). A preliminary examination of fluid inclusion data (in association with AFTA and vitrinite reflectance measurements) from five WOS wells by Parnell et al. (1999) noted anomolously hot fluids in sandstone samples as young as Paleocene in age, and demonstrated that such activity persisted at least into the Eocene. In this study we have extended this preliminary work to include 47 samples from nine wells, ranging in age from Precambrian Basement to Miocene in order to record the stratigraphic interval(s) in which anomolously hot fluid inclusions are present;

2. temporally restricted features (e.g. rapid cementation events). Quartz cementation may occur as a single rapid event due to solubility decrease with falling temperature (short-lived fluid flow events), or as a result of a longer time-scale response to compaction during burial. The paper presents the results of a Scanning Electron Microscope cathodoluminescence (SEM-CL) study of quartz cements carried out on 43 sandstone samples from 16 WOS wells to determine whether a quartz cement phase attributable to a single, widespread event could be recognized;

3. direct indicators of mineral precipitation from high temperature fluids. Dickite (a high temperature polytype of kaolin, stable above $90^{\circ} \mathrm{C}$ to $120^{\circ} \mathrm{C}$ occurs in many hydrothermal systems and its presence in sandstones may, therefore, be directly indicative of elevated palaeotemperatures.

\section{GEOLOGICAL SETTING}

The regional geology of the West of Shetland area has been described by many authors (e.g. Bailey et al. 1987; Stoker et al. 1993; Lamers \& Carmichael 1999). The region is floored by crystalline basement gneisses of Lewisian affinity overlain by half-graben rift sequences of Permo-Triassic age. Late JurassicEarly Cretaceous rifting led to deposition of organic shales and restricted sandstones on a thin Early Jurassic shale sequence. Late Cretaceous rifting and normal faulting were followed by the deposition of extensive marine sediments, prior to Paleocene-Eocene volcanism. In a study of thermal effects of the Tertiary Cuillins Intrusive Complex on organic-rich midJurassic shales, sediments more than $15 \mathrm{~km}$ from the complex were immature, suggesting that igneous intrusion was not a viable regional mechanism for maturation of shallow-buried sediments (Thrasher 1992). In areas affected by fluid migration, however, localized heat flow may have moved hydrocarbonbearing sediments into the oil generation window (Thrasher 1992). Hot fluid migration has been identified in the palaeothermal record in several wells from the UK Atlantic Margin (Parnell et al. 1999). At a local scale the impact of hot fluid migration is significant, with a fivefold increase in thermal maturity relative to a normal maturity predicted from normal geothermal gradient in the absence of intrusions (Holmes et al. 1999). The extent of this heating may have been favourable for hydrocarbon generation in certain regions and could also have driven fluids from Mesozoic to Tertiary levels (Bjørkum \& Nadeau 1998). Post-volcanism uplift during the Tertiary was followed by the deposition of Early Eocene paralic to continental sediments and Eocene-Oligocene marine clastic sediments prior to deposition of a veneer of Pliocene and younger sediments now exposed at the sea floor.

\section{ANALYTICAL METHODS}

All samples analysed were selected from the core of commercial wells located in the West of Shetland. Three additional wells (referred to here as 204/A, 204/B and 204/C) are anonymous. Sample sizes were, in general, small, extracted from core and sidewall core. Fluid inclusion wafers were prepared by INROCK Drilling Services Ltd UK, using standard methods. Fluid inclusion wafers were examined using a calibrated Linkam THM600 heating-freezing stage attached to an Olympus BH-2 petrographic microscope, and measured with the aid of a video screen coupled to a Nikon OPTIPHOT 2-POL microscope. The Linkam THM 600 was calibrated using organic standards of known melting point. The Linkam THM 600 stage is extremely sensitive and is accurate in heating and freezing within increments of $0.1^{\circ} \mathrm{C}$ between temperatures of $-196^{\circ} \mathrm{C}$ and $600^{\circ} \mathrm{C}$. Homogenization temperature $\left(T_{\mathrm{h}}\right)$ measurements were determined using a heating rate of $10^{\circ} \mathrm{C} \mathrm{min}^{-1}$ at intervals of $0.1^{\circ} \mathrm{C}$. First and final ice melting temperatures $\left(T_{\mathrm{e}}\right.$ and $T_{\mathrm{m}}$ respectively) were measured at a heating rate of $1^{\circ} \mathrm{C} \mathrm{min}^{-1}$. Hydrocarbon inclusions, which fluoresce under ultra-violet light, were photographed using a Nikon Eclipse 600 UV microscope fitted with a Nikon HB-10104AF mercury source. No independent measurements of temperature or pressure were obtained during the course of these analyses and, therefore, these values are only minimum temperature estimates.

SEM-CL images were collected on a Phillips XL-30CP SEM located in the Department of Geology \& Geophysics, University of Edinburgh. Fragments of double-polished impregnated fluid inclusion wafers (approximately $100 \mu \mathrm{m}$ thick) were mounted onto glass slides using a double-sided adhesive carbon disk, and then carbon coated to produce a conducting layer. A series of test images were taken to standardize operating conditions in order to image quartz textures. Under the chosen conditions carbonates are nonluminescent. The majority of images were taken using an accelerating voltage of $15 \mathrm{kV}$, with an approximate beam current at the specimen of $1 \mathrm{nA}$ and a working distance of approximately $1 \mathrm{~mm}$ from the cathodoluminescence (CL) detector. The CL detector consists of a fully retractable arm with a parabolic mirror mounted at one end, and was left in place when taking secondary electron images, but removed from above the sample when backscattered electron images were obtained. SEM-CL images are digital, with individual pixel brightness a function of the intensity of the CL signal at each beam spot. The beam is scanned and the signals from each point recombined to generate the image. Various frame integration, resolution and scan rates were used depending on the detrital grain and matrix luminescent response.

$\mathrm{X}$-ray diffraction (XRD) analyses were performed on a Phillips X-Ray Diffractometer at the Department of Geology \& Geophysics, University of Aberdeen. Analyses were carried out from $3-50^{\circ}$ using $\mathrm{Cu} \mathrm{K}$ (radiation at $36 \mathrm{kV}, 24 \mathrm{~mA}$ ).

All stable isotope analyses were carried out at the Scottish Universities Research Reactor Centre, East Kilbride. Samples chosen for stable isotope analysis were hand separated, due to the small initial sample volumes available. Oxygen isotope analyses were obtained using fluorinated samples plasma-ashed at $650^{\circ} \mathrm{C}$ (Clayton \& Mayeda 1963). Hydrogen isotopic analyses were undertaken using the method of Bigeleisen et al. (1952).

\section{RESULTS}

\section{Fluid inclusion thermometry}

Existing anomalously hot fluid inclusion data in the literature are predominantly from Paleocene samples (Parnell et al. 1999, 2001); in this study wells with post-Paleocene sandstone samples have been targeted to determine whether the thermal anomaly continued beyond the Paleocene and, if so, to what 


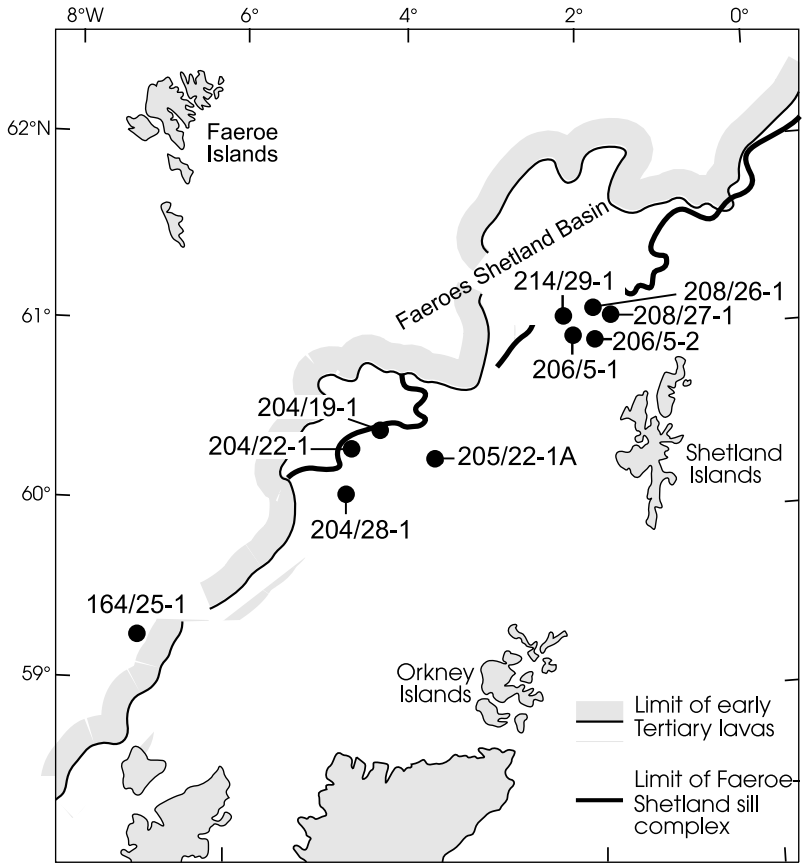

Fig. 1. Map showing location of wells studied by fluid inclusion microthermometry. Also shown are the eastern limits of outcrop of early Tertiary lavas and outcrop of the Faeroe-Shetland sill complex.

extent. The number of released wells with post-Paleocene sandstone cuttings is limited. Eight wells were sampled in which both post-Paleocene and Paleocene or older samples could be measured to produce a profile of fluid inclusion homogenization temperatures, plus one additional well that allowed comparison of Upper Paleocene and older levels (Fig. 1). The problem of assessing a post-Paleocene temperature record from limited wells is exacerbated by the very limited degree of cementation in these shallow samples. Although healed microfractures through grains can be measured in most samples, their significance has to be assessed with care in order to determine that they are not inherited: this assessment is made from petrographic evidence and from the consistency of the data obtained from them. The cements measured in the post-Paleocene samples are quartz and/or calcite. The cements are believed to be relatively early, as the host samples have high minus-cement porosities (i.e. cementation had occurred before significant compaction). This is common in carbonatecemented sands, not typically due to hot fluids, but early re-crystallization of shell fragments. It is uncommon in quartzcemented sandstones. Where cements yield anomalous temperatures, we infer a maximum age for hot fluid from the age of the sample. Where cements yield normal, relatively lowtemperature data, we cannot state that no hot fluid was present at the depositional age. However, because the cements appear to be early, the stratigraphic distribution of hot fluid signatures is a reasonable guide to their time span. The occurrence of hot fluid signatures in the post-Paleocene samples is summarized in Table 1. The stratigraphic range has been divided the into the following intervals:

1. latest Paleocene-earliest Eocene, including sections allocated to the Sele Formation;

2. Early Eocene, including samples allocated to the Balder Formation and/or the Ypresian;

3. Mid to Upper Eocene. Several well logs do not subdivide this further;

4. Oligocene.

A total of 47 samples from nine wells (Figs $2 \mathrm{a}-\mathrm{h}$ ) yielded fluid inclusion data. Data from two close wells (208/26-1 and 208/27-1) were plotted together. The profiles exhibited the following patterns:

1. several wells show evidence for high temperatures in cements and crosscutting trails in the Paleocene/early Eocene section. For example, in 206/5-2 temperatures in the Tertiary samples record notably hotter temperatures than in the Jurassic and Triassic sections. In some wells, these 'hot' signatures are absent in the shallowest samples, in 208/27-1 in the Mid Eocene, in 204/22-1 in the Upper Eocene and 204/28-1 in the Oligocene. In 164/25-1, there is also a marked drop in temperature recorded between the Paleocene and Eocene, although the Eocene temperature at up to $120^{\circ} \mathrm{C}$ is still high for the burial depth. The hot signature persists down into the Jurassic in both 204/22-1 and 204/28-1, but in these cases the Jurassic samples immediately underlie the Paleocene, i.e. there is hydrologic connectivity between Tertiary and pre-Tertiary. Elsewhere Jurassic rocks do not exhibit the hot signature, and it is absent in the crystalline basement sample in 204/22-1, i.e. there is a lower limit to the signature. In 204/19-1, where the stratigraphic control on hot fluid distribution was first determined prior to this project, the Cretaceous section includes thick mudrocks that would have isolated Paleocene sands from Cretaceous and older sands. No hot fluid signature is evident in the pre-Cretaceous sands, indicating that the hot fluids were focused in the Tertiary section and could not access deeper aquifers. Although high temperatures are recorded in many Paleocene and Eocene samples, it is notable in 204/28-1 and 204/19-1 that the most marked anomaly occurs near the top of the Tertiary section (Eocene in both these wells). Similarly the shallower Paleocene samples in 214/29-1 yield the highest temperatures: no Eocene samples were available for measurement in this well. This suggests that although hot fluids were able to enter the Tertiary aquifer, they were either focused along certain horizons, or they did not leave a record at all levels. Their particular occurrence in the upper part of several wells could reflect higher porosities in shallower rocks, or ponding beneath impermeable horizons.

2. The profile through well $205 / 22-1 \mathrm{~A}$ shows no marked thermal anomaly at any level. However, the moderate temperatures encountered in Eocene and Oligocene samples

Table 1. Occurrence of hot-fluid signatures in post-Paleocene samples West of Shetland, as recorded by fluid inclusion microthermometry

\begin{tabular}{lccccccccc}
\hline & $214 / 29-1$ & $208 / 27-1$ & $208 / 26-1$ & $206 / 5-2$ & $206 / 5-1$ & $205 / 22-1$ a & $204 / 22-1$ & $204 / 28-1$ & $164 / 25-1$ \\
\hline Oligocene & - & - & - & - & - & MOD & - & LOW \\
Middle Eocene-Upper Eocene & - & LOW & LOW-MOD & - & LOW & MOD & LOW & HIGH \\
Lower Eocene & - & - & - & - & - & - & HIGH & MOD & LOW-MOD \\
Upper Paleocene-Lower Eocene & HIGH & - & - & HIGH & LOW-MOD & - & - & - & - \\
\hline
\end{tabular}

Grey columns represent significant geographical separation. 

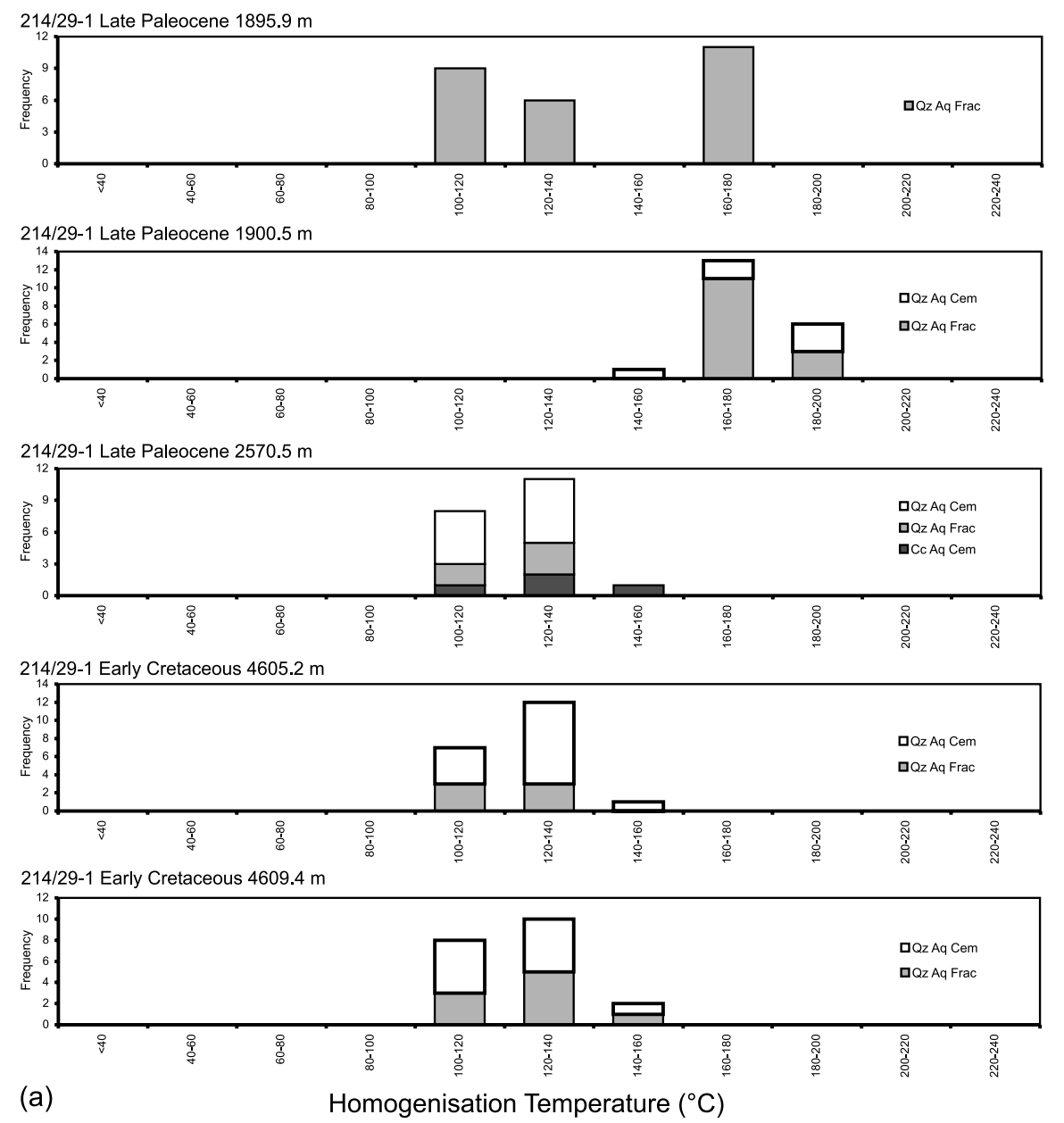

Fig. 2. (a).

are still higher than might be expected from the burial depth. We speculate that this reflects its setting eastward of a structural high, the southern end of the Flett Ridge, which may have inhibited up-dip flow from deep basinal regions to the west, such that only a weak anomaly is expressed. The calcite cement in the shallow levels of well 206/5-1 yields only monophase inclusions (by convention, representing temperature $<60^{\circ} \mathrm{C}$ ). The healed microfractures in grains in these young samples are probably inherited: there is no modal value for temperatures in the microfractures. There is no unequivocal evidence for anomalous temperatures in this well, which is also east of the Flett Ridge. Well 206/5-2 is also east of the ridge, but is adjacent to a major fault that could have acted as a conduit for hot fluids.

Green et al. (1999) used a present-day geothermal gradient of c. $30^{\circ} \mathrm{C} \mathrm{km}^{-1}$ for $204 / 19-1$. Due to the amount of postEarly Tertiary burial in this region, they assume that the maximum limit to the Early Tertiary palaeogeothermal gradient is $c .90^{\circ} \mathrm{C} \mathrm{km}^{-1}$. This means that Early Tertiary heat flow rates of up to three times present-day values may have been present and recorded in the homegenization temperatures of the cements. The Cretaceous data (Fig. 3) are mostly consistent with a palaeogeothermal gradient less than that of the present day. Most of the Paleocene data for 204/19-1 lie between the present-day value $\left(c .30^{\circ} \mathrm{C} \mathrm{km}^{-1}\right)$ and that proposed by Green et al. (1999) as the maximum for the Early Tertiary $\left(\right.$ c. $\left.90^{\circ} \mathrm{C} \mathrm{km}^{-1}\right)$. However, it can be shown that the Eocenehosted data for this well, as well as some of the Paleocene- hosted data, imply that elevated thermal values (of up to at least three times the present-day geothermal gradient) were present at this time.

We believe that the high temperatures in several wells do reflect the entrapment of anomalously high-temperature fluids. There is no evidence for an additional component in the inclusion fluids which might complicate the homogenization behaviour. Processes that may influence the vapour/liquid ratio of inclusions and, hence, their homogenization temperatures, such as trapping of vapour-liquid mixtures and necking down during inclusion entrapment can be discounted because adjacent inclusions yield consistent temperatures rather than the range of temperatures that would reflect a variable proportion of entrapped vapour.

\section{Fluid inclusion petrography}

Fluid inclusions were measured exclusively in quartz cement. It was possible to distinguish primary inclusions which occur in quartz cement (either at grain-overgrowth boundaries or within overgrowths) and secondary inclusions which occur in healed microfractures cross-cutting grains. Where trails of secondary inclusions cut cement, they are clearly post-depositional. Where cement is lacking, trails are assumed to be post-depositional where they exhibit consistent orientations or can be traced from one grain to another or contain hydrocarbon inclusions. Isolated inclusions within grains, or trails that cannot be deduced to be post-depositional, are excluded. A general observation, not limited to this study, is that some trails yield 

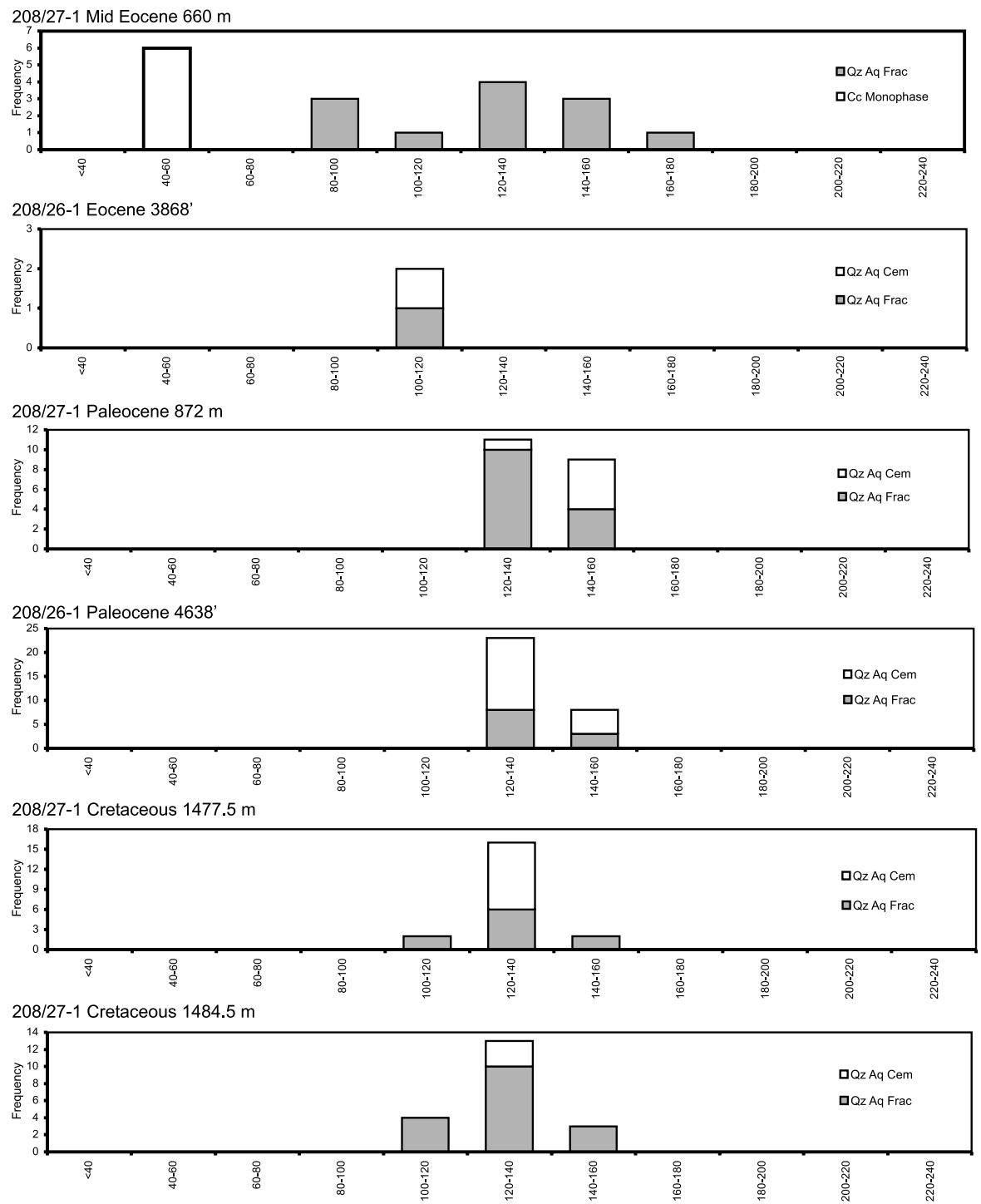

(b)

Homogenisation Temperature $\left({ }^{\circ} \mathrm{C}\right)$

Fig. 2. (b).

data comparable with those from cement in the same sample, indicating that microfracture healing is part of the cementation process (Parnell et al. 2001).

The inclusions measured are mostly in the size range $2-5 \mu \mathrm{m}$ and have rounded to oval shapes. Where hydrocarbon inclusions occur, they may be up to $10 \mu \mathrm{m}$ size. Mixed inclusions of water and hydrocarbon have not been observed, although traces of one fluid along the walls of an inclusion of the other fluid could go unnoticed. Ice melting temperatures were all below zero and there is no evidence for clathrate formation which would represent significant methane or carbon dioxide contents.

Histograms of homogenization temperature data are shown in Figures $2 \mathrm{a}-\mathrm{h}$. The higher temperatures $\left(>150^{\circ} \mathrm{C}\right)$ occur in both primary and secondary populations of inclusions. Where salinity data are available, calculated from ice melting temperatures (Bodnar 1993), they are cross-plotted against homogenization temperature, distinguished by well (Figs 4a, b). There is no consistent distinction in salinity between primary and secondary inclusions in a single well. The cross-plots for homogenization temperature and salinity data show a contrast between the wells in Quad 206 and those in Quads 204 and 208. The two Quad 206 (Fig. 4a) wells show no relationship between temperature and salinity. The Quad 204 and 208 (Fig. 4b) wells show a general trend of higher salinity with higher temperature.

The simplest interpretation of an increase of salinity with temperature is that the high temperatures reflect rapid introduction of hot brines from deep levels in the basin to the west, and deeper brines are generally more saline. The lack of a trend in Quad 206 wells (Fig. 4a) may be related to their location further inboard on the continental margin, where deep brines could access less easily. The high salinities at lower temperatures in the Quad 206 wells could also reflect more saline porewaters derived from sabkha facies in the DevonianCarboniferous of the adjacent Clair Field (Allen \& MangeRajetsky 1992).

As many of the samples contain hydrocarbon inclusions, aqueous inclusions are probably gas-saturated and pressure corrections are unnecessary. If such corrections were to be applied, the high temperatures would become even more anomalous. 

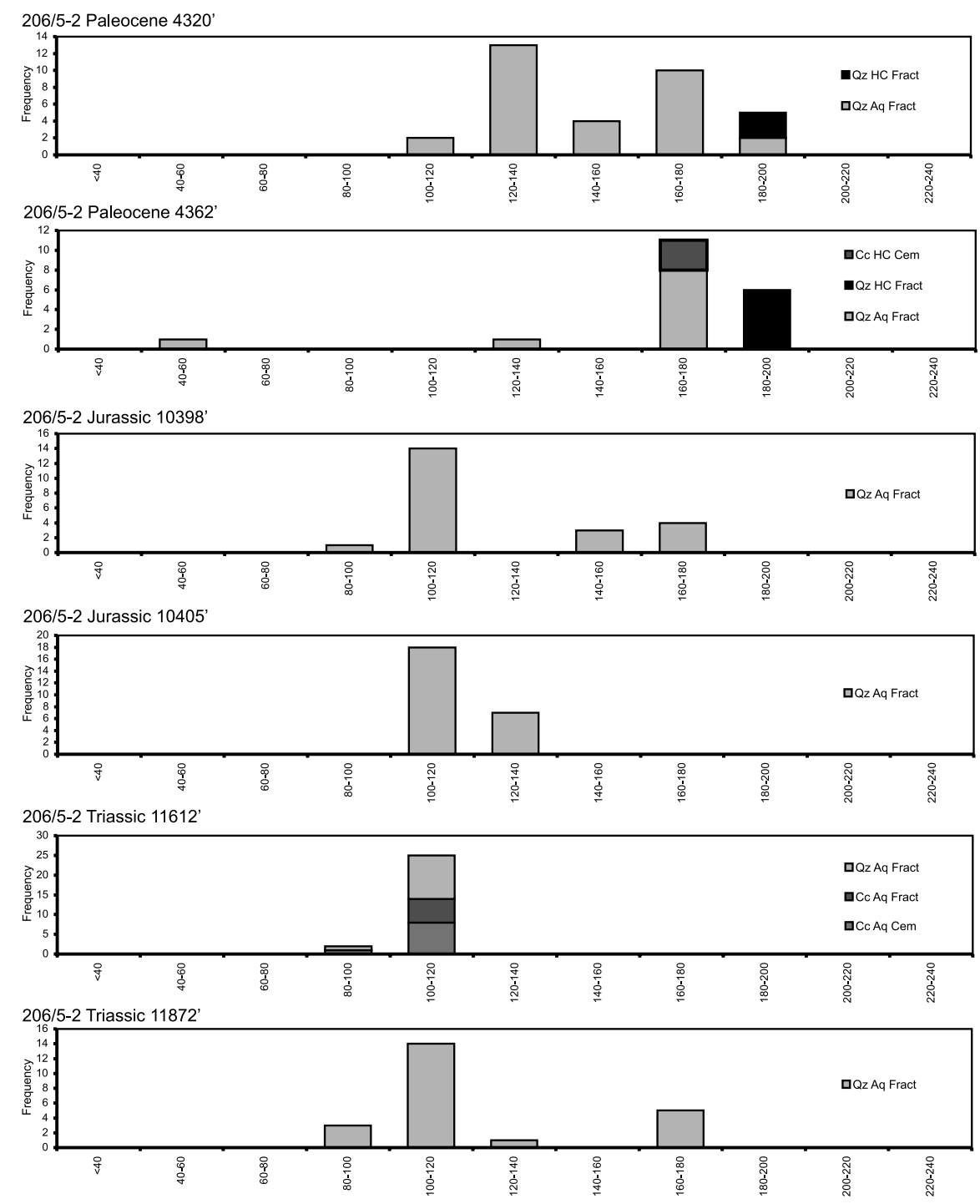

(c)

Homogenisation Temperature $\left({ }^{\circ} \mathrm{C}\right)$

Fig. 2. (c).

\section{Cathodoluminescence imaging of cements}

A summary of cement observations summarized by stratigraphy is shown in Table 2. The majority of samples, regardless of age, contain late carbonate cements, with both dolomite and calcite present in variable amounts. In samples where both carbonate cements and quartz overgrowths are present (e.g. 206/11-1, $3569.2 \mathrm{~m}$; Figs 5a, b), carbonate clearly post-dates quartz growth. Of the three Eocene samples studied in CL, only one (204/22-1, $1540 \mathrm{~m})$ contained significant silica overgrowths or cement. Overgrowths in this sample were strongly zoned. Cements and overgrowths in Paleocene samples fell in two groups, delimited by the presence or absence of a characteristic unzoned silica cement. Where present, cements are variable in abundance and are often restricted in samples containing carbonate. Typically, extensively carbonate-cemented samples have no quartz cement. In several cases (e.g. 204/19-1, 8808.0', 204/A) they have nucleated on detrital quartz in the form of small euhedral quartz prisms (e.g. Fig. 5c) as well as euhedral grain overgrowths. Pre-Paleocene samples (Jurassic and Cretaceous) contain no unzoned quartz cements - all quartz cements are zoned in CL. Zonation is typically blocky to irregular, with an earlier weakly luminescing phase overgrown by brighter-luminescing quartz, but oscillatory zoned examples (e.g. Fig. 5b) have been noted.

\section{SEM and XRD studies of kaolin polytypes}

Fifteen samples of kaolin-bearing sandstones from ten WOS wells were imaged using SEM-secondary-electron-imagery in order to determine whether dickite and kaolinite could be distinguished in situ. Crystal morphology was used to discriminate between low temperature kaolinite, intermediate kaolinitedickite and high temperature dickite (e.g. McAuley et al. 1994; Osborne et al. 1994). Kaolin polytypes (which for these purposes can be subdivided into kaolinite, intergrowths of kaolinite and dickite and pure dickite) become progressively more 'blocky' in appearance with increasing temperature (McAuley et al. 1994; Beaufort et al. 1998). In the WOS samples studied, the majority of kaolin had one of two morphologies:

- very fine-grained aggregates (grain size of 2-3 $\mu \mathrm{m}$ ) of grain-coating individual platelets on detrital feldspars (Fig. 6a);

- coarser, more blocky aggregates up to $20 \mu \mathrm{m}$ long in quartz-lined fractures (Fig. 6b, c). 

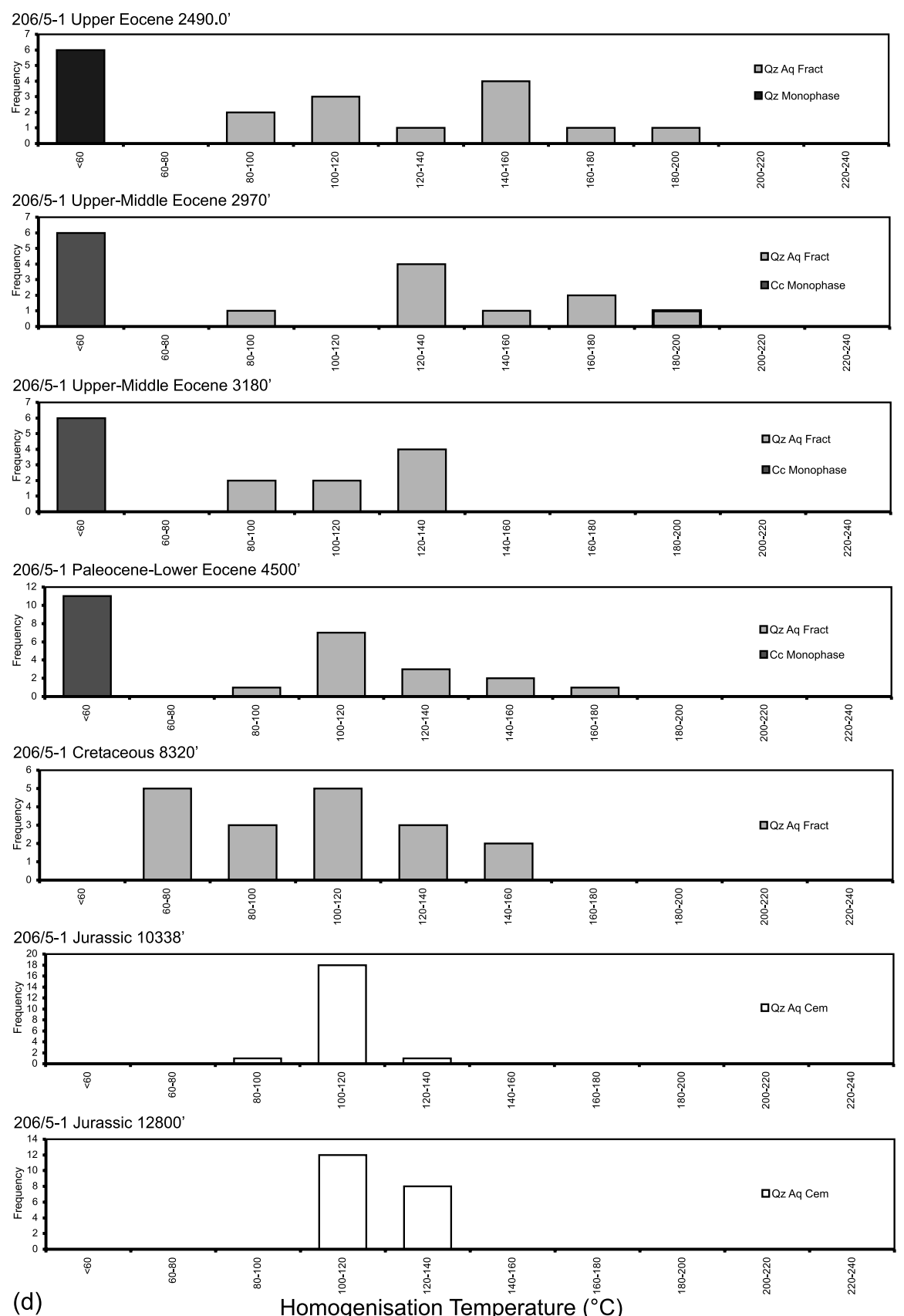

(d)

Fig. 2. (d).

Beaufort et al. (1998) noted that fine-grained kaolinite occurring on feldspar is a common feature of weathering and, therefore, the fine-grained kaolin recorded here may represent either detrital kaolinite or kaolinite formed during the primary stages of feldspar weathering. As feldspar dissolves during progressive burial, kaolin morphologies coarsen and become more euhedral due to recrystallization. Kaolinite coarsened by recrystallization (and intergrowths of kaolinite with dickite pseudomorphing kaolinite) are commonly referred to in the literature as 'blocky' or 'intermediate' kaolinite (Osborne et al. 1994; Beaufort et al. 1998). Intermediate kaolinite may, however, form by hydrothermal processes involving the illitization of early kaolinite by hot fluids (Lanson et al. 1996), as well as by burial-related recrystallization. Given the setting of intermediate kaolinite in WOS samples (where it is restricted to fractures associated with quartz) and the occurrence of kaolinite-illite intergrowths in many samples (e.g. Fig. 6c), we suggest that hot fluid-related illitization is responsible for the coarse aggregates of intermediate kaolinite recorded here.

$\mathrm{XRD}$ analysis was carried out to determine whether kaolin polytypes could be used as indicators of high-temperature fluid flow. Due to small sample volumes used in the study (mainly sidewall core or small core fragments) and difficulties in extracting sufficient pure kaolin material from these samples, only four samples were studied.

Because of the limited sample set, any conclusions as to the use of XRD as a high-temperature fluid flow indicator are limited and, here, only the data collected are discussed. As noted above, two types of kaolin material were recorded in WOS samples, grain-coating material on feldspar grains and fracture-fill intermediate kaolinite associated with quartz. Two samples from each setting were analysed. XRD traces from 

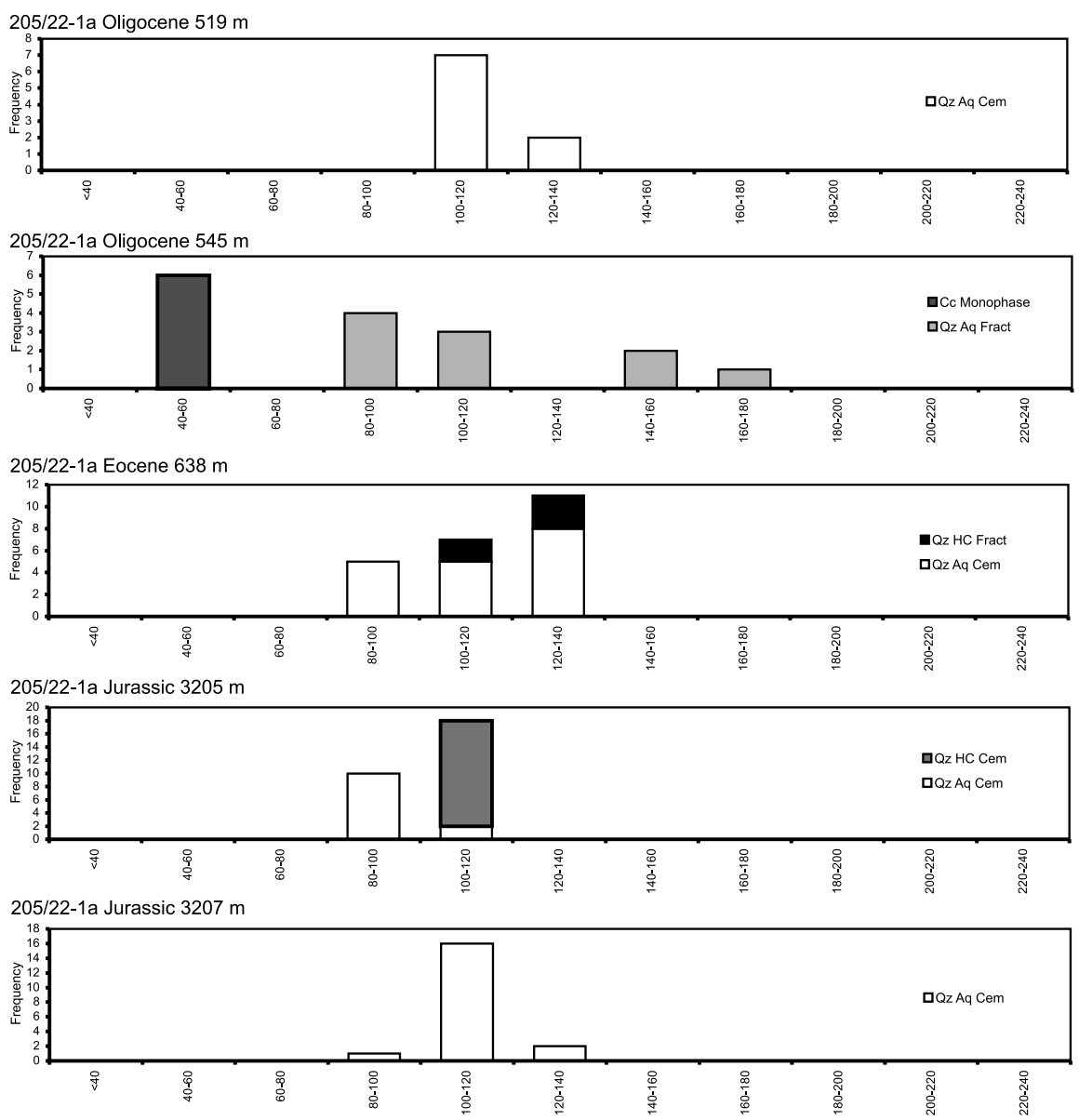

(e)

Homogenisation Temperature $\left({ }^{\circ} \mathrm{C}\right)$

Fig. 2. (e).

matrix kaolin samples (208/27-1, $1483.5 \mathrm{~m}$ and 208/27-2, $4235.1 \mathrm{~m}$ ) indicate only small amounts of kaolinite and no evidence for dickite (Fig. 7). Extensive contamination by both $\mathrm{K}$-feldspar and plagioclase is seen in both matrix kaolinite samples. Feldspar (plagioclase and K-feldspar) and a small amount of calcite dominate matrix kaolinite XRD traces. In contrast, XRD traces from fracture-fill intermediate kaolinite samples show both dickite and kaolinite components and little contamination from other material. No pure dickite was noted in XRD.

\section{Stable isotope analysis of kaolin}

Isotope data from seven samples in five wells (Table 3) were plotted against literature values for various morphologies and polytypes of kaolinite from North Sea examples (Fig. 8). In addition to the relationship between morphology and temperature of precipitation discussed above, previous isotopic studies of kaolin in sandstones have also demonstrated a direct correlation between morphology and isotope chemistry. In a compilation of North Sea data, Osborne et al. (1994) noted that low temperature 'vermiform' kaolinite was characterized by high $\delta \mathrm{O}$ values and strongly depleted $\delta \mathrm{D}$. Similar kaolinite compositions were noted in upper Jurassic reservoir sandstones from the Magnus Province, east Shetland Basin (Fallick et al. 1993). Higher temperature polytypes of kaolin, including samples described as kaolinite (McAuley et al. 1994), 'blocky' or 'intermediate' kaolinite (Glassman et al. 1989) and dickite (McAuley et al. 1994) are characterized by lower $\delta \mathrm{O}$ values.
Kaolin material extracted from WOS wells gives dickite- or intermediate kaolinite-type isotopic signatures (Fig. 8), with the exception of sample 214/29-1 (2563 m) which is enriched in $\delta^{18} \mathrm{O}$ relative to the other WOS samples and plots in the low temperature kaolinite field.

In order to determine the nature of the fluids that WOS kaolinite may have equilibrated with, a number of scenarios have been examined. These include

- precipitation in equilibrium with present-day meteoric waters;

- precipitation in equilibrium with ancient marine waters;

- precipitation in equilibrium with magmatic waters related to Tertiary volcanic activity;

- post-crystallization re-equilibration with present-day formation waters;

- precipitation in equilibrium with mixed fluids.

Calculations were performed using the following isotope fractionation equations: O - Savin \& Lee (1988) and Sheppard \& Gilg (1996); D - Lambert \& Epstein (1980). In general, temperatures calculated using Savin \& Lee (1988) were $10^{\circ} \mathrm{C}$ higher than those using Sheppard \& Gilg (1996) and more consistent with published temperature data. Osborne et al. (1994) calculated a maximum precipitation temperature for vermiform kaolinite of around $50^{\circ} \mathrm{C}$ using the oxygen fractionation coefficients of Savin \& Lee (1988), which recalculate at $40^{\circ} \mathrm{C}$ using Sheppard \& Gilg (1996). In order to maintain consistency with existing published data, all calculations quoted here were, therefore, performed using the oxygen fractionation 

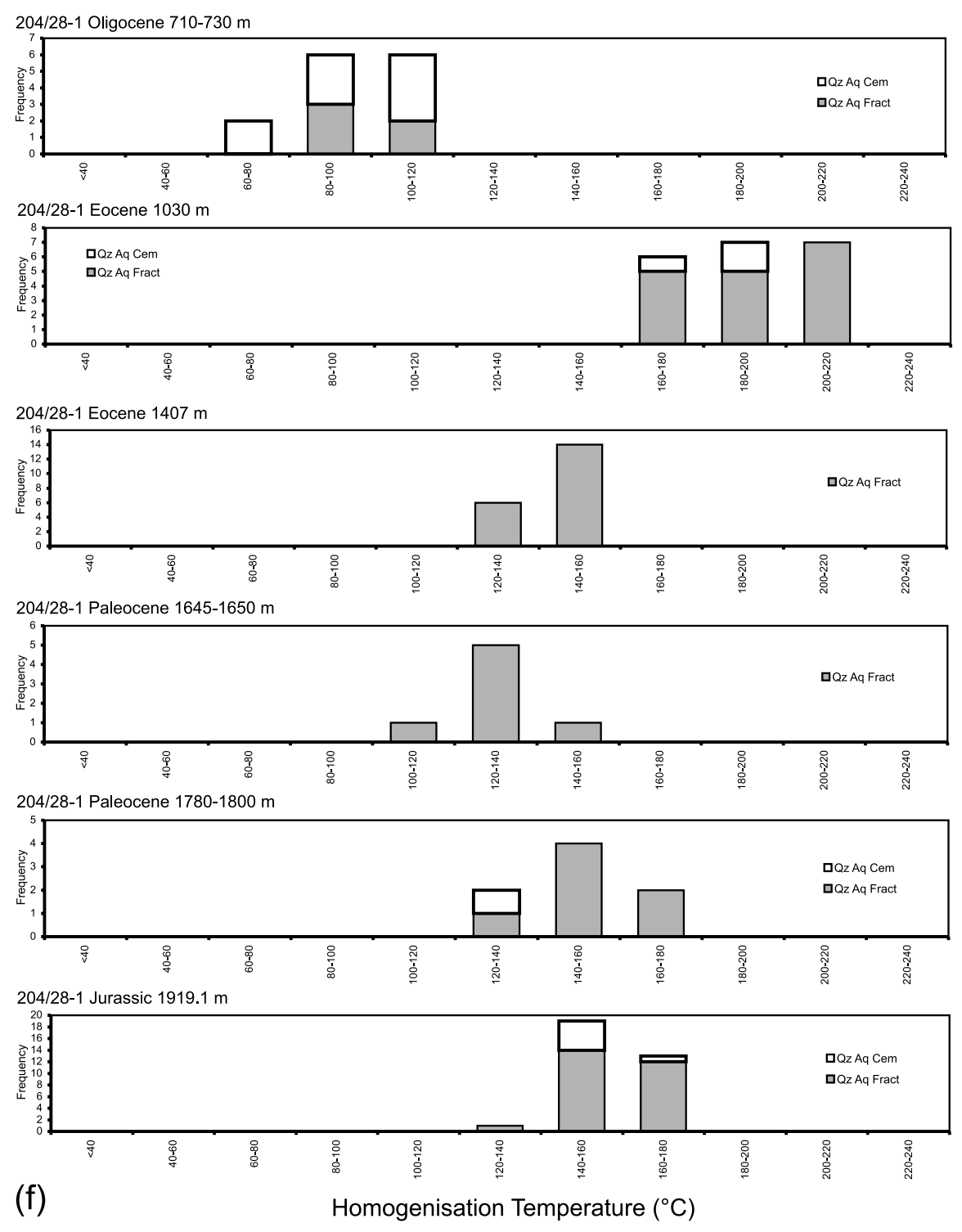

Fig. 2. (f).

values of Savin \& Lee (1988). Figure 9 shows the best-fit calculated kaolinite compositions that would have grown in equilibrium at temperatures of between $80^{\circ} \mathrm{C}$ and $100^{\circ} \mathrm{C}$, and with fluids of between $\delta \mathrm{D}=-3 \%$ and $-6 \%$. These samples would all have equilibrated with a fluid of similar composition.

\section{DISCUSSION}

\section{Stratigraphic focusing of hot fluid signatures}

Anomalously hot palaeotemperatures have been retained in aqueous and hydrocarbon inclusions in quartz cements and microfractures in several wells. In Tertiary samples temperatures are increased by up to $40^{\circ} \mathrm{C}$ when compared to the underlying sediments (wells 204/28-1, 206/5-2, 208/27-1 and 214/29-1) and temperature-depth profiles from these wells show a pattern characteristic of lateral rather than vertical heat transport. In the case of 204/28-1 the hot fluid signature is absent from overlying Oligocene samples. Hot fluids may be sourced from hydrothermal vents or by rapid up-dip flow from deep basin levels. Existing models for WOS fluid migration invoke up-dip fluid flow (Parnell et al. 2001). Stratigraphic focusing WOS would be enhanced by sandstone geometries in the Paleocene (Lamers \& Carmichael 1999), where continuous Tertiary sandstone fairways drape Late Cretaceous-Early Tertiary post-rift sequences. Up-dip migration in these fairways would isolate hot fluids from underlying sediments except where hydrologic connectivity exists. In examples where high palaeotemperatures have been recorded in Jurassic samples (e.g. 204/22-1 and 204/28-1), these samples immediately underlie Tertiary sandstones and, therefore, may have experienced hot fluid flow. Up-dip migration (as opposed to a localized hydrothermal origin) is also consistent with the stable isotope data presented here (discussed more fully below) which predict that kaolinite of mean WOS isotopic value would precipitate in equilibrium with meteoric waters that have a composition of approximately $\delta^{18} \mathrm{O}=-4 \%, \delta \mathrm{D}=-21 \%$ at $80^{\circ} \mathrm{C}$ to $90^{\circ} \mathrm{C}$. As primary magmatic waters typically have $\delta^{18} \mathrm{O}$ values ranging between $+5 \%$ and $+10 \%$ o (much higher than the calculated fluid $\delta^{18} \mathrm{O}$ value), we believe WOS kaolin is unlikely to have precipitated in equilibrium with magmatic waters.

\section{Cementation during hot fluid flow}

Quartz cement studies show characteristic stratigraphic distributions. Quartz cements are interpreted as having formed early 

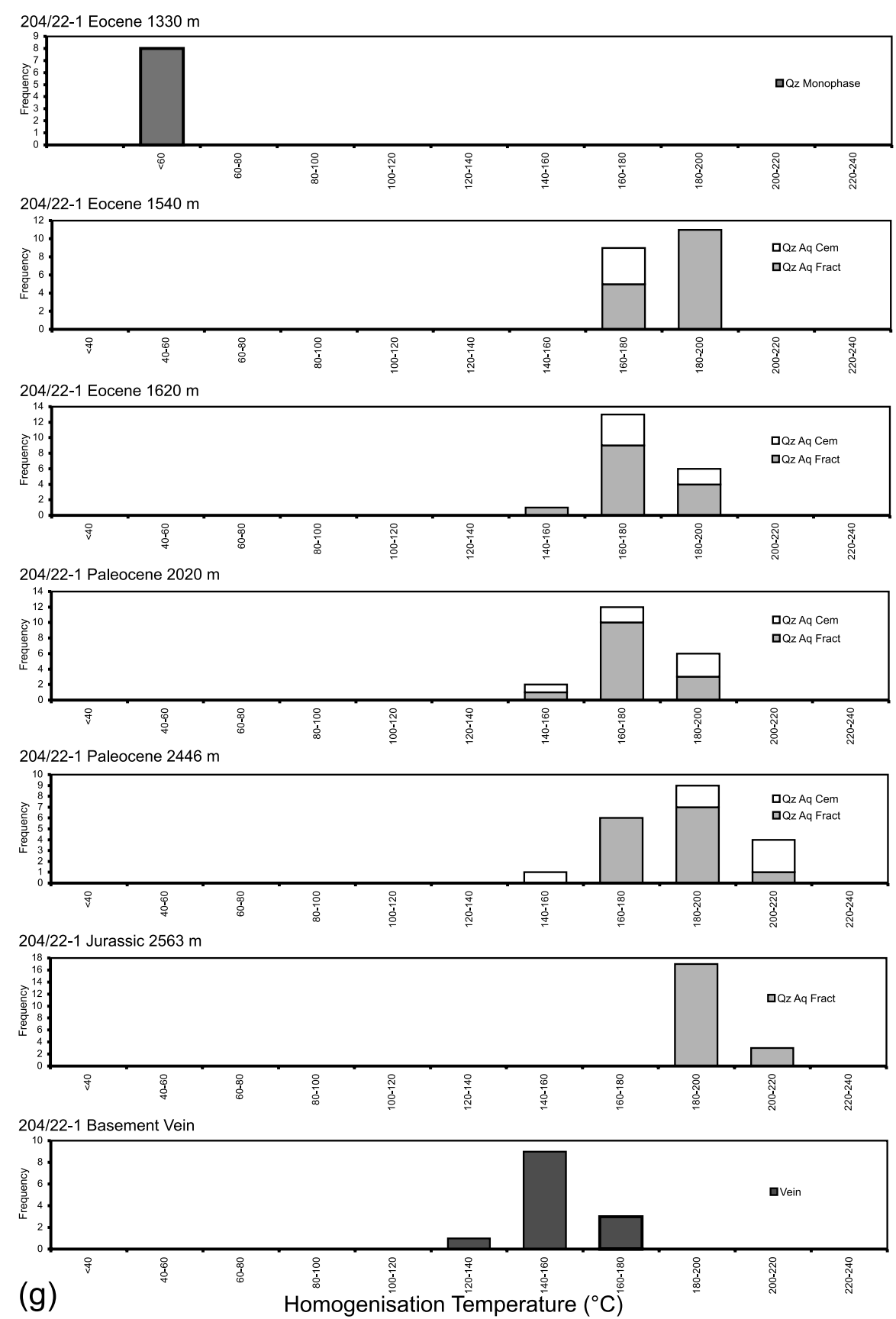

Fig. 2. (g).

in the diagenetic history, and, as such, the stratigraphic age of the sample in which they occur can be regarded as a maximum age of formation. Unzoned quartz cements (often forming as multiple small euhedral prisms) are restricted to samples of Paleocene age, whilst oscillatory zoned cements occur in older samples (Cretaceous-Jurassic). Oscillatory zoned quartz cements are the most commonly recorded quartz overgrowths (Hogg et al. 1992; Lyon et al. 2000). The growth dynamics leading to oscillatory zonation are not well understood in detail (Holten et al. 2000), but it is now generally accepted that oscillatory zoning involves growth at a rate which permits the build up of chemical change at the crystal growth front (Bolton et al. 1996). Changes in the composition of the saturated fluid from which the crystal grows will alter growth rate (since the structure of quartz cannot easily accept impurities) (Allègre $e t$ al. 1981; Shore \& Fowler 1996; Holten et al. 2000) and zonation detectable by CL is produced. Oscillatory zoning requires relatively slow crystallization rates compared to unzoned growth, where growth occurs more quickly than the formation of chemical gradients (Watt et al. 1997). Zoned cements may grow by closed system diffusional growth or open system episodic growth, while unzoned cements are thought to grow by open system continuous growth (Lyon et al. 2000). Unzoned cements are, therefore, best explained by rapid precipitation and, consistent, in this case, with open system episodic growth from a cooling fluid emplaced in Tertiary samples.

In contrast to this episodic cementation, silica cements in Cretaceous samples show complex zonation, which we consider more typical of prolonged cementation during basin subsidence. Comparison of fluid inclusion data with cement distribution shows a good correlation between palaeofluid temperature and predicted cement type. Samples 204/28-1 

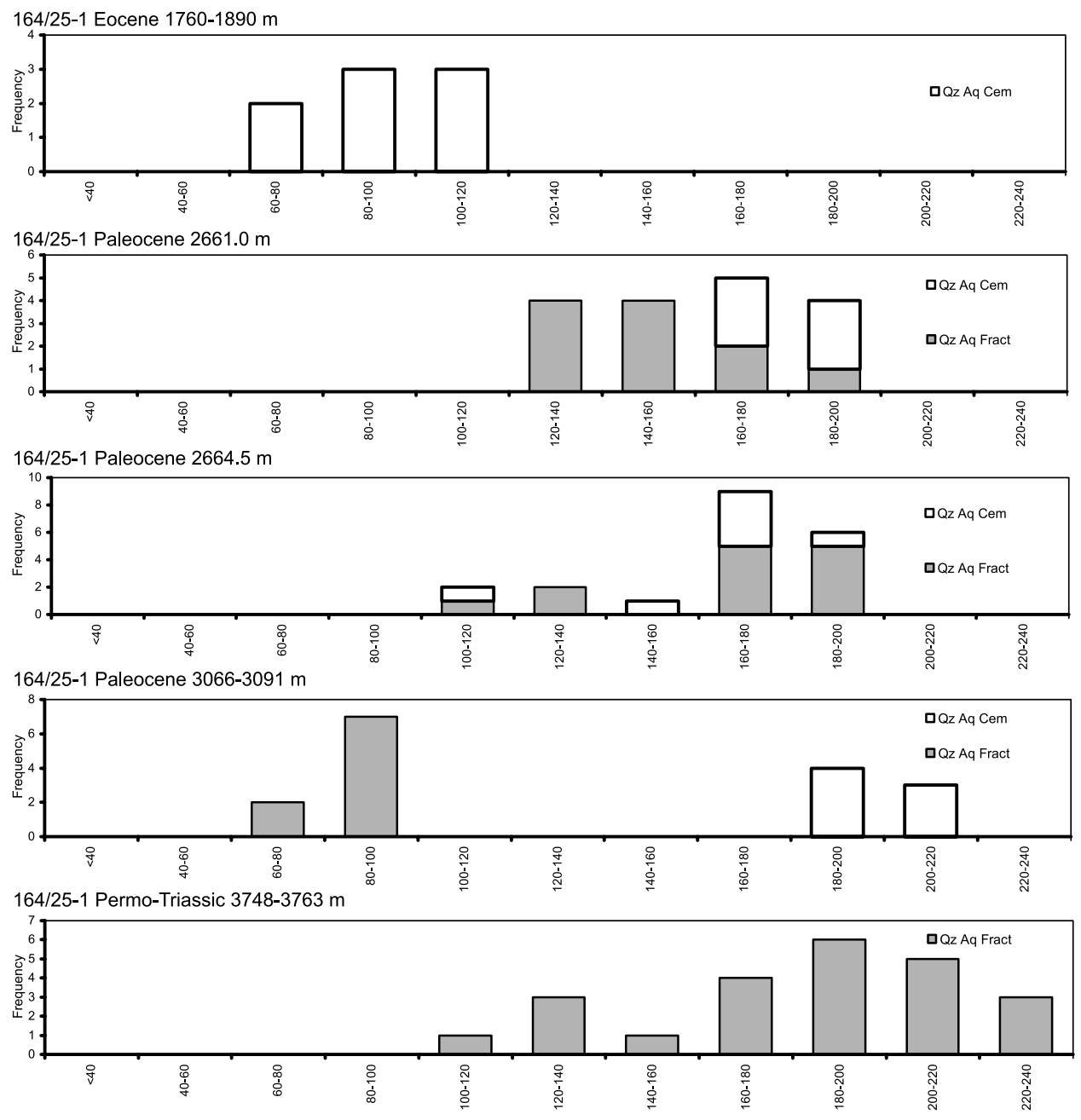

(h)

Homogenisation Temperature $\left({ }^{\circ} \mathrm{C}\right)$

Fig. 2. (h).

Fig. 2. Vertical fluid inclusion profiles for the nine West of Shetland wells shown in Figure 1, arranged from (a) north (214/29-1) to (h) south (164/25-1). Two geographically close wells (208/26-1 and 208/27-1) were plotted together in (b). Each profile is labelled by well (e.g. 214/29-1), stratigraphy (e.g. Late Paleocene) and depth (in metres (m) or feet (')). Each profile is comprised of several individual samples (arranged by depth, with the oldest at the base) and within each sample the inclusion data are labelled by mineral (Qz, quartz; Cc, carbonate), inclusion composition (Aq, aqueous; HC, hydrocarbon) and setting (Cem, cement or grain-overgrowth boundary; Frac, fracture (primary or secondary)). Several examples of monophase inclusions were recorded and noted.

(1030 m) and 164/25-1 (2664.5') both show anomolously high palaeotemperatures at Paleocene stratigraphic levels and unzoned cements, while zoned cements were noted in samples 208/27-1 (1477.5 m) and 214/29-1 (2570 m). Only one sample $(204 / 22-1,1540 \mathrm{~m})$ showed a combination of hot palaeotemperatures and zoned quartz cement. It should be noted, however, that 'normal' quartz cement (which we take to mean locally sourced quartz cement produced by pressure solution, Hertzian fracturing and localized reprecipitation (Milliken \& Laubach 2000)) is always zoned when imaged using a sensitive enough CL detector. The quartz CL signal is strongly defect related, and, since no perfect crystal has ever been grown, zonation will almost always be present. It is suggested, however, that there may not be a consistent link between cement morphology and $T_{\mathrm{h}}$ because cement morphology is a function of precipitation rate and not temperature. A rapidly precipitated igneous quartz crystal grown in a single phase of crystallization, from a saturated and rapidly moving melt at $900^{\circ} \mathrm{C}$ can be unzoned, whereas a slowly growing crystal crystallizing at $700^{\circ} \mathrm{C}$, in a relatively static melt where grain boundary-melt interfaces may change composition, will almost undoubtedly show zonation (Watt et al. 1997).

Waldehaug (1994) suggests that the lowest measurement of fluid inclusion homogenization temperatures for aqueous inclusions can be used as a best estimate of the temperature of initial quartz cementation in a sample. Precipitation rates can be calculated from homogenization temperatures and burial history modelling. This paper proposes that these WOS data suggest that rapid precipitation has taken place. Waldehaug (1994) concludes that there is a direct exponential correlation between increasing precipitation rate and increasing temperature. Therefore, it is possible for cements to be precipitated rapidly from cooling fluids, especially when they are cooling from elevated temperatures. For example, from his data, rapid quartz precipitation could occur at temperatures of $c .90^{\circ} \mathrm{C}$ and above, although it is faster at higher temperatures.

\section{Source of hot fluids}

Having demonstrated the presence of hot fluids, stable isotopic analysis may allow determination of the source of these fluids. 


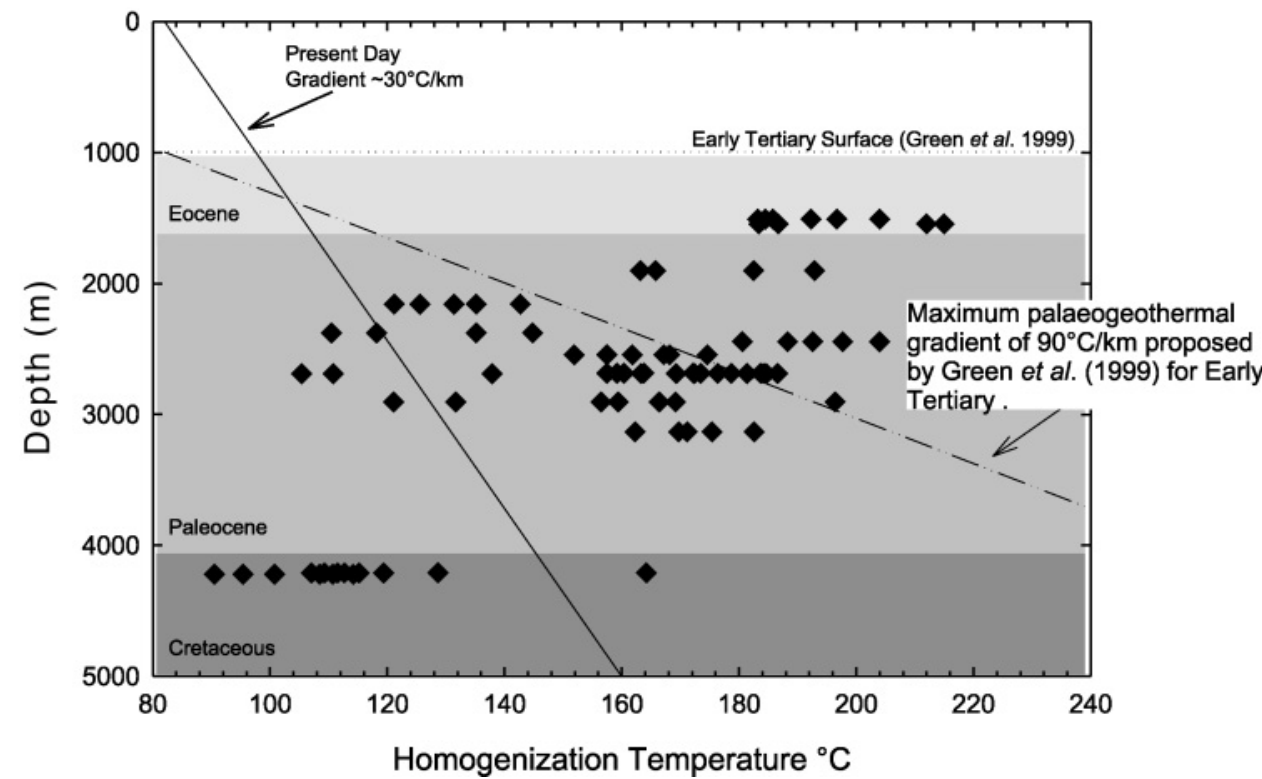

Fig. 3. Present-day geothermal gradient and maximum Early Tertiary palaeogeothermal gradient (after Green et al. 1999) for well WOS 204/19-1. A cross-plot of depth $(\mathrm{m})$ against $T_{\mathrm{h}}$ is superimposed upon these gradients. These data indicate that during the Late Paleocene and Eocene the thermal regime must have been near to, or above, $90^{\circ} \mathrm{C} \mathrm{km}^{-1}$. A constant surface temperature of $10^{\circ} \mathrm{C}$ is assumed.
It has already been noted that the fluids with which the kaolinite equilibrated were not of magmatic origin. Isotopic calculations (Glassman et al. 1989; Fallick et al. 1993; McAuley et al. 1994) predict that kaolinite of mean WOS composition would precipitate in equilibrium with meteoric waters which
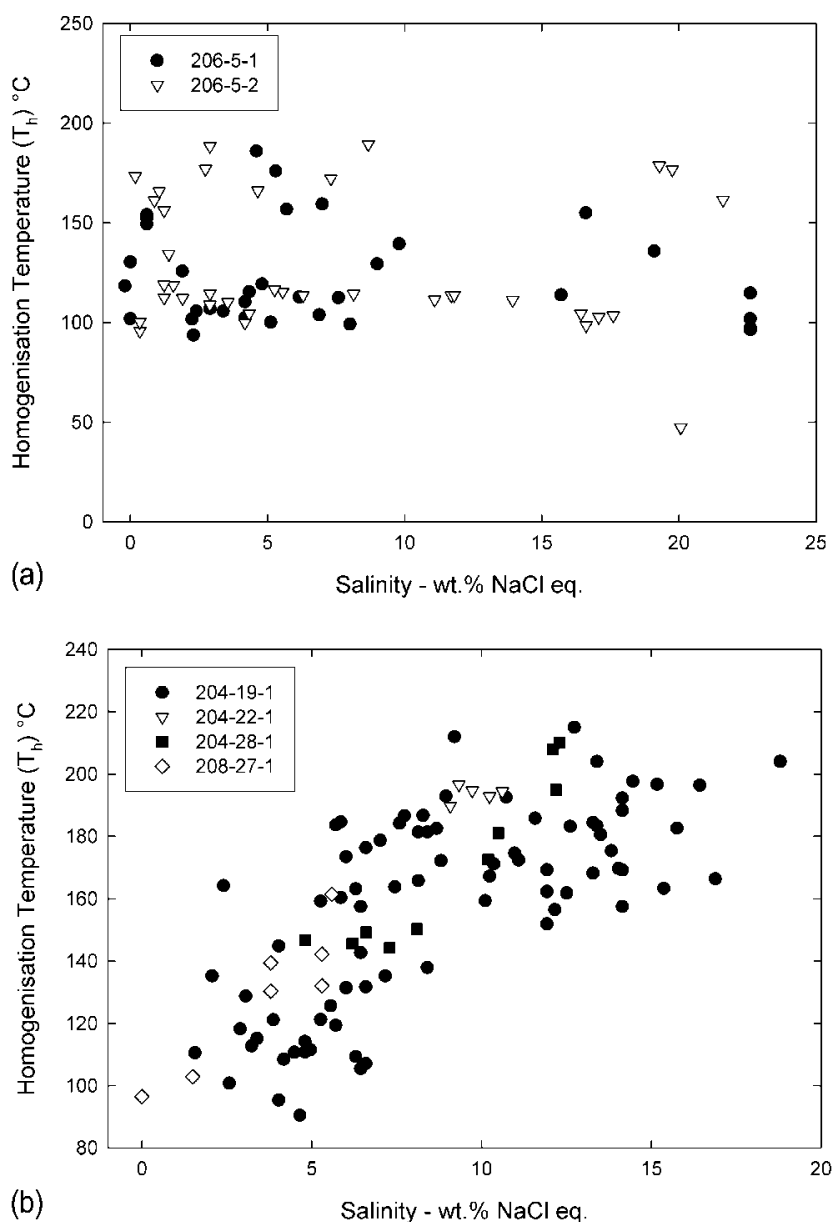

Fig. 4. Cross-plots of salinity and $T_{\mathrm{h}}$ for (a) WOS Block 206; and (b) WOS Blocks $204 \& 208$, showing the contrasting characteristics of these regions. have a composition of approximately $\delta^{18} \mathrm{O}=-4 \%, \delta \mathrm{D}=$ $-21 \%$ at $80^{\circ} \mathrm{C}$ to $90^{\circ} \mathrm{C}$. These temperatures are consistent with literature observations that blocky kaolinite precipitates at temperatures in excess of $70-80^{\circ} \mathrm{C}$. When fluid compositions for all WOS samples (with the exception of GW-01-05) are plotted, it is apparent that they lie on a linear trend depleted in $\delta^{18} \mathrm{O}$ relative to meteoric waters (Fig. 10) and, therefore, cannot have precipitated directly from unmodified present-day meteoric water compositions.

Experimental studies have shown that post-crystallization exchange of $\mathrm{O}$ isotopes between kaolinite and porewater is negligible at reservoir temperatures, although D isotope exchange has been reported by Longstaffe \& Ayalon (1990) amongst others. Furthermore, Osborne et al. (1994), in a study of kaolinite in the Thistle Oilfield, concluded that postprecipitation exchange between clays and pore fluids at presentday reservoir temperatures has not occurred. No isotopic data from present-day WOS formation waters exist in the literature, so it is not possible to directly estimate whether re-equilibration of WOS kaolinites with their corresponding formation waters has occurred. Literature compositions for reservoir pore fluids in the North Sea, however, typically fall between $\delta^{18} \mathrm{O}=-2 \%$ to $+2 \%$ o (Brint 1989; Ziegler et al. 2001), significantly higher than calculated fluids in equilibrium with WOS kaolinite. Present-day equilibration of WOS kaolinites with modern formation waters is, therefore, considered unlikely.

Pre-Miocene seawater is estimated to have had a composition of $\delta^{18} \mathrm{O}=-1 \%, \delta \mathrm{D}=-7 \%$ (Sheppard 1986). Calculated kaolinite compositions in equilibrium with a fluid of this composition at temperatures between $80^{\circ} \mathrm{C}$ and $100^{\circ} \mathrm{C}$ have $\delta^{18} \mathrm{O}$ values between $+15.2 \%$ and $+17.2 \%$, significantly higher than those of the WOS kaolinites. It is unlikely, therefore, that kaolinite precipitated from unmodified pre-Miocene marine fluids at temperatures consistent with growth of blocky kaolinite. The modification of original seawater compositions by interaction with basalts or volcaniclastic sediments leads to a depletion of fluid $\delta^{18} \mathrm{O}$ to levels below the meteoric water line (MWL). It is possible, therefore, that high $\delta \mathrm{D}$ WOS samples precipitated in equilibrium with isotopically modified marine porewater which reacted with basalts or volcaniclastic sediments (Lawrence \& Gieskes 1981; Sheppard 1986). It is also possible that they could they have a small Mesozoic meteoric water component (see below). 
Table 2. Distribution of cement types in sandstones from West of Shetland

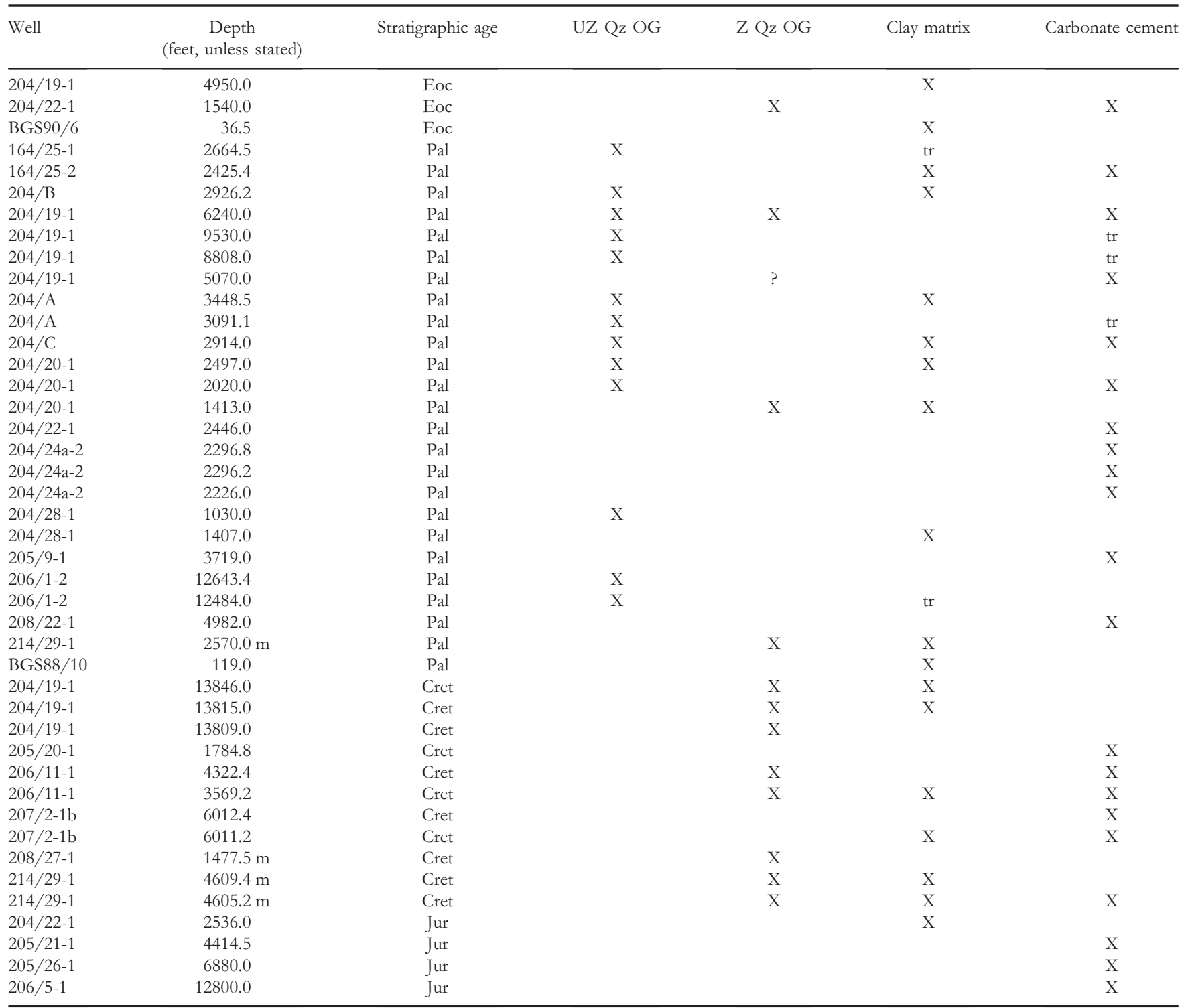

Abbreviations: UZ Qz OG, unzoned quartz overgrowths; Z Qz OG, zoned quartz overgrowths; Eoc, Eocene; Pal, Paleocene; Cret, Cretaceous; Jur, Jurassic; tr, trace.

The approximate end-member fluids which could have mixed to produce the range of compositions recorded in WOS kaolinites range between $\delta^{18} \mathrm{O}=-3 \%$ o to $-6 \%, \delta \mathrm{D}=-15 \%$ to $-40 \%$, with all but GW-01-05 showing a strong positive linear correlation along the line $\delta \mathrm{D}_{\mathrm{w}}=7.14 \delta^{18} \mathrm{O}_{\mathrm{w}}+14$.

A strong positive linear correlation between $\delta \mathrm{O}$ and $\delta \mathrm{D}$ in kaolinites from the Magnus Sandstone, North Sea, was interpreted by Fallick et al. (1993) as evidence for precipitation of kaolinite from pore fluids of varying isotopic composition at a single temperature. They suggested that a two-phase mixture comprising of present-day formation waters and modified Cretaceous meteoric water. As discussed above, present-day formation water compositions are unknown for WOS wells. If the WOS formation water composition is to represent one component of the calculated fluid mixing line, it must be depleted in $\delta^{18} \mathrm{O}$ relative to typical formation waters (e.g. Fallick et al. (1993) $\delta^{18} \mathrm{O}=+2 \%$ ) and, more importantly, depleted in $\delta^{18} \mathrm{O}$ relative to the present-day MWL. Fallick et al. (1993) have noted that formation waters are, however, typically shifted to higher $\delta^{18} \mathrm{O}$ values relative to the MWL. The mean value of formation water compositions in Brent Group lithologies from the Oseberg Field, Norwegian North Sea (Ziegler et al. 2001) is $\delta^{18} \mathrm{O}=-1.7 \%$ o to $-19.4 \%$, with only the most $\delta^{18} \mathrm{O}$ depleted sample $\left(\delta^{18} \mathrm{O}=-4.4 \%\right.$, to $-19 \%$ ) similar to the postulated upper end-member for WOS fluids. It seems unlikely, therefore, that present-day formation waters could represent the upper end-member on the calculated fluid mixing line unless those of the WOS region are significantly depleted in $\delta^{18} \mathrm{O}$ relative to typical values. It is suggested, instead, that an isotopically modified marine porewater is the high $\delta^{18} \mathrm{O}$ component of a two-phase mixing line. The low $\delta \mathrm{D}$ mixing component required to produce the observed range of calculated fluid compositions has a composition of around $\delta \mathrm{D}=-6 \%$ to $-40 \%$. These data are consistent with published Cretaceous and Jurassic meteoric waters which have $\delta^{18} \mathrm{O}$ values of $-6 \%$ to $-7 \%$ (Hamilton et al. 1987; Fallick et al. 1993). Tertiary meteoric waters are estimated to have had $\delta^{18} \mathrm{O}$ of approximately $10 \%$, lower than those of Mesozoic meteoric waters but still a possible mixing component. The calculated fluid compositions that would be in equilibrium with 
(a)

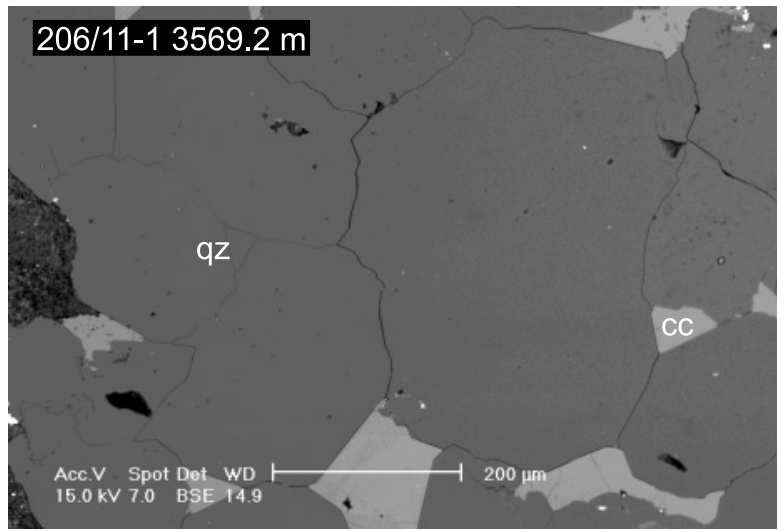

(b)

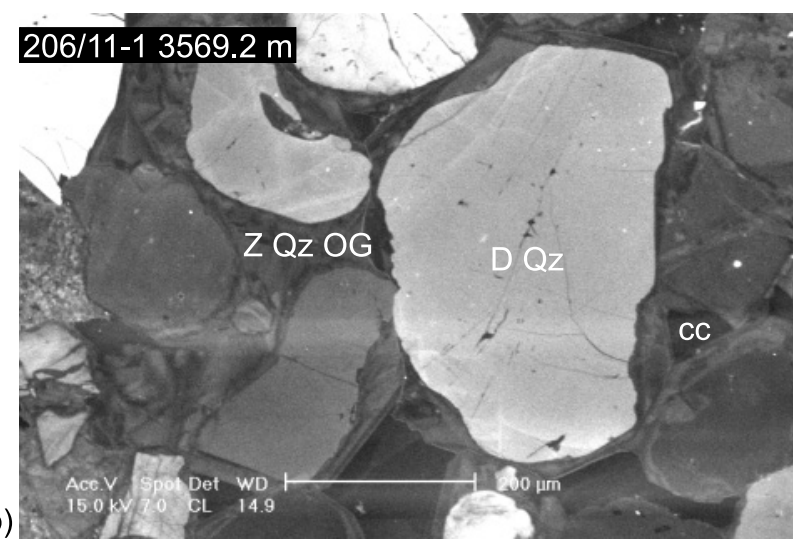

(c)

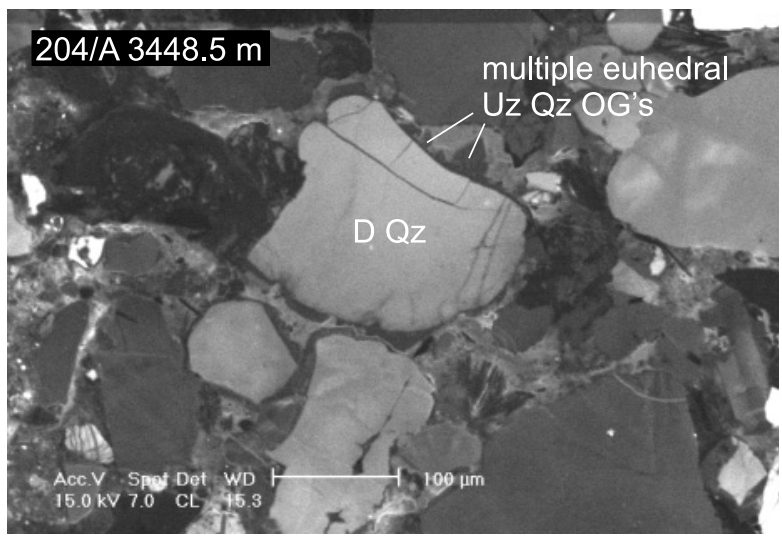

Fig. 5. (a) Backscattered electron image of quartz-cemented sandstone of Cretaceous age from well 206/11-1 (3569.2 m). Wellcemented quartz (dark grey, Qz) with planar to concavo-convex grain contacts shows planar crystal faces (lower left, centre) against porosity-filling calcite cement (cc). (b) SEM-CL image of the same area, showing rounded to almost skeletal detrital quartz grains (D Qz) overgrown by strongly zoned silica cements. Under the chosen operating conditions calcite shows only weak luminescence. Z Qz OG, zoned quartz overgrowths? (c) SEM-CL image of Paleocene sandstone from well 204/A (3448.5 m). Cements in this sample are narrower, show only very faint luminescence and no evidence for zonation and form as isolated euhedral prisms and overgrowths (unzoned quartz overgrowths) on detrital quartz (D Qz). The pale grey, moderately luminescent material in the porosity of this sample is resin, indicating relatively high porosity.

WOS kaolinite compositions can, therefore, be considered as a mixture of Mesozoic and/or Tertiary meteoric waters and trapped marine porewaters which have isotopically altered

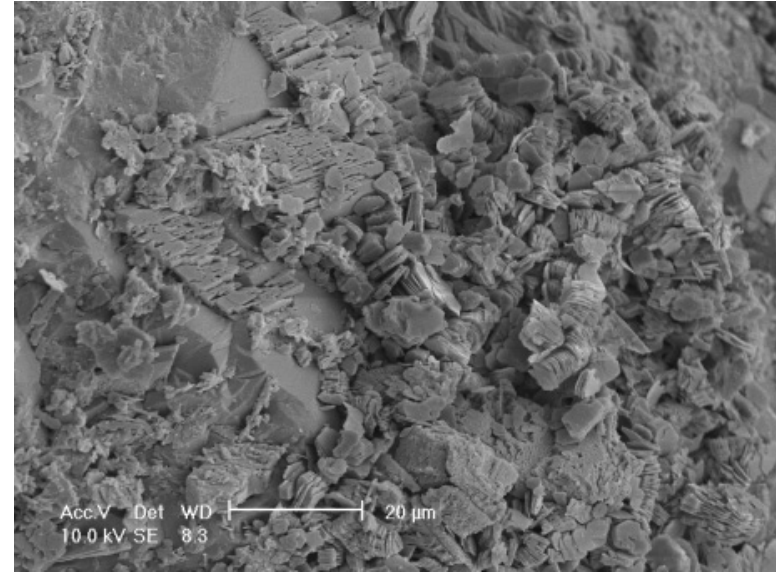

(b)

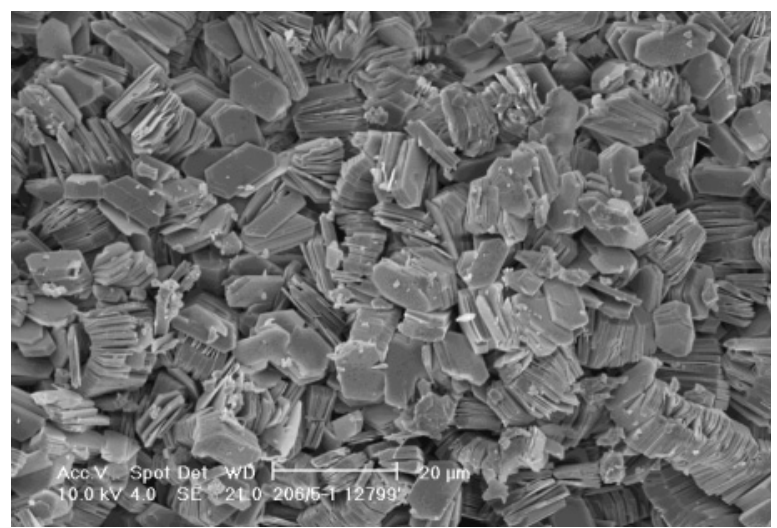

(c)

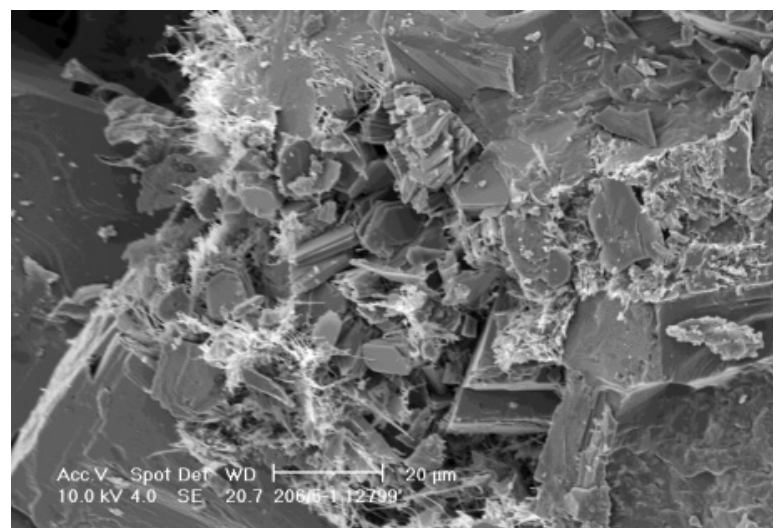

Fig. 6. (a) Relatively fine-grained kaolinite clusters (right) and smaller, less well-formed kaolinite grains on an altered K-feldspar grain (left) from a Paleocene sandstone in well 214/29-1, $1898.4 \mathrm{~m}$ (b) Euhedral, 'intermediate' kaolinite aggregates in a quartz-lined fracture from 206/5-1 (12 999'). (c) Intergrowths of illite and kaolinite on calcite in a fracture from 206/5-1 (12 999').

by interaction with volcaniclastic and/or basaltic rocks, presumably during Tertiary activity. An important observation in 206/5-2 (and previously in 204/19-1) is that the high temperatures are recorded in oil inclusions as well as aqueous inclusions, i.e. the hot fluid pulse involved oil migration. This observation clearly indicates a need for further research.

\section{CONCLUSIONS}

This study confirms that the stratigraphically constrained hot fluid flow event recorded by Parnell et al. (1999) in well $214 / 29-1$ is present over a wider area in the West of Shetland area, and to shallower depths, than previously recorded. 


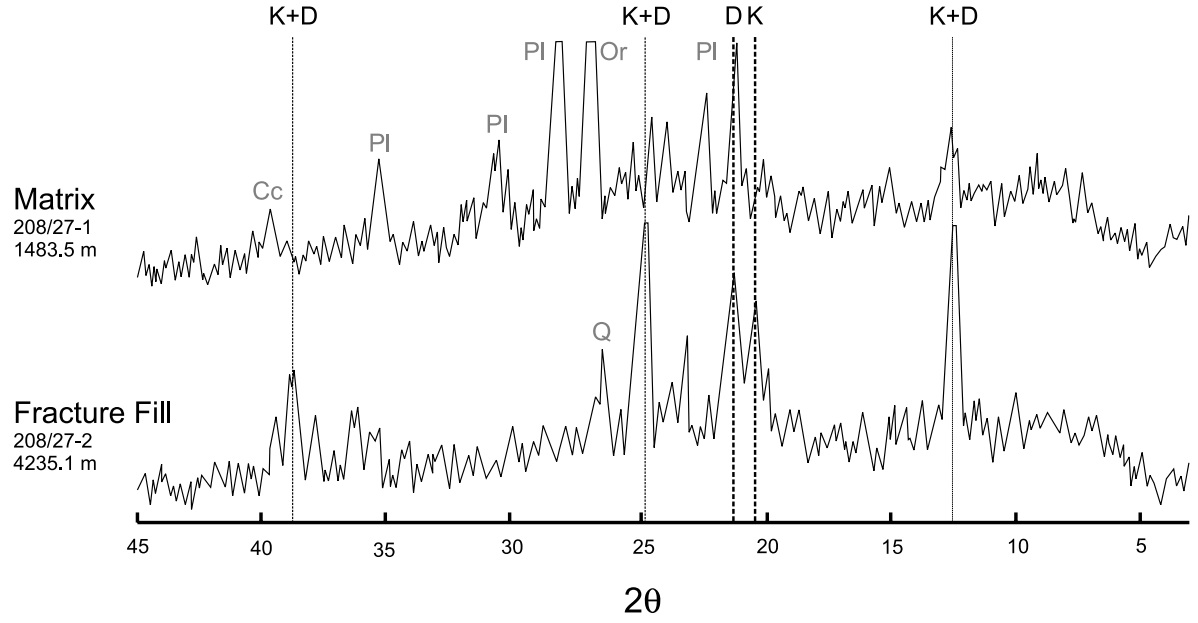

Fig. 7. XRD traces of fine-grained matrix kaolinite (upper - well 208/27-1, $1483.5 \mathrm{~m}$ ) and fracture-fill intermediate kaolinite (lower - well 208/27-2, $4235.1 \mathrm{~m})$. Fracture-fill intermediate kaolinite shows a strong

kaolinite+dickite signal $(\mathrm{K}+\mathrm{D})$, while matrix kaolinite shows only a very weak low (kaolinite peak due primarily to contamination by weathered feldspar. Cc, calcite; Pl, plagioclase; Or, orthoclase; D, dickite; K, kaolinite; Q, quartz.

Table 3. Stable isotope data for West of Shetland kaolinite samples

\begin{tabular}{lccc}
\hline Location & Depth (feet) & O & Repeat O \\
\hline $204 / 30 a-2$ & 8009.4 & 13.3 & -42 \\
$206 / 5-1$ & 12799.0 & 11.7 & -62 \\
$208 / 27-2$ & 4194.2 & 12.4 & -50 \\
$208 / 27-2$ & 4462.9 & 13.5 & -41 \\
$208 / 27-2$ & 4518.1 & 13.0 & -42 \\
$208 / 27-2$ & 4235.1 & 14.6 & -42 \\
$214 / 29-1$ & 2563.8 & 17.4 & -41 \\
& & 13.0 & -52.9 \\
& Mean WOS & 13.2 & -56.3 \\
& Mean 208/27-2 & 12.4 & -49 \\
\hline
\end{tabular}

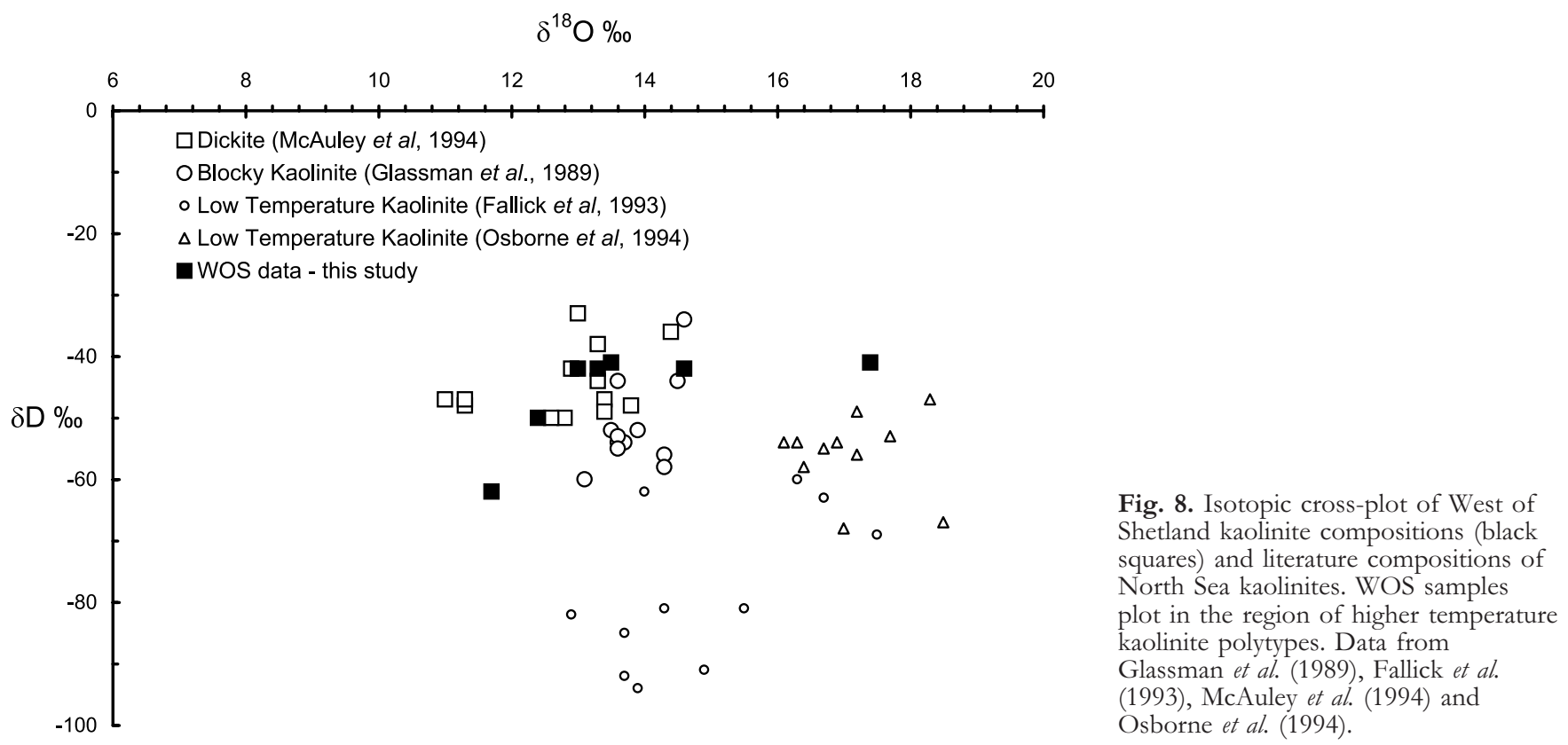

Using a combination of fluid inclusion microthermometry, CL petrography and detailed morphological and isotopic studies of kaolin phases, a range of features has been highlighted that can be used to identify hot fluid flow. Anomalously high temperatures, previously noted in Paleocene samples from well 214/ 29-1, were also recorded in Paleocene samples from 206/5-2, in lower Eocene samples in 204/22-1 and in mid- to upper Eocene samples in 204/28-1. These temperatures were recorded in early quartz cements and it is, therefore, suggested that the stratigraphic age of the samples recording hot fluid flow approximates the age of fluid entrapment. If this is the case, hot fluid flow can be demonstrated to have occurred from 

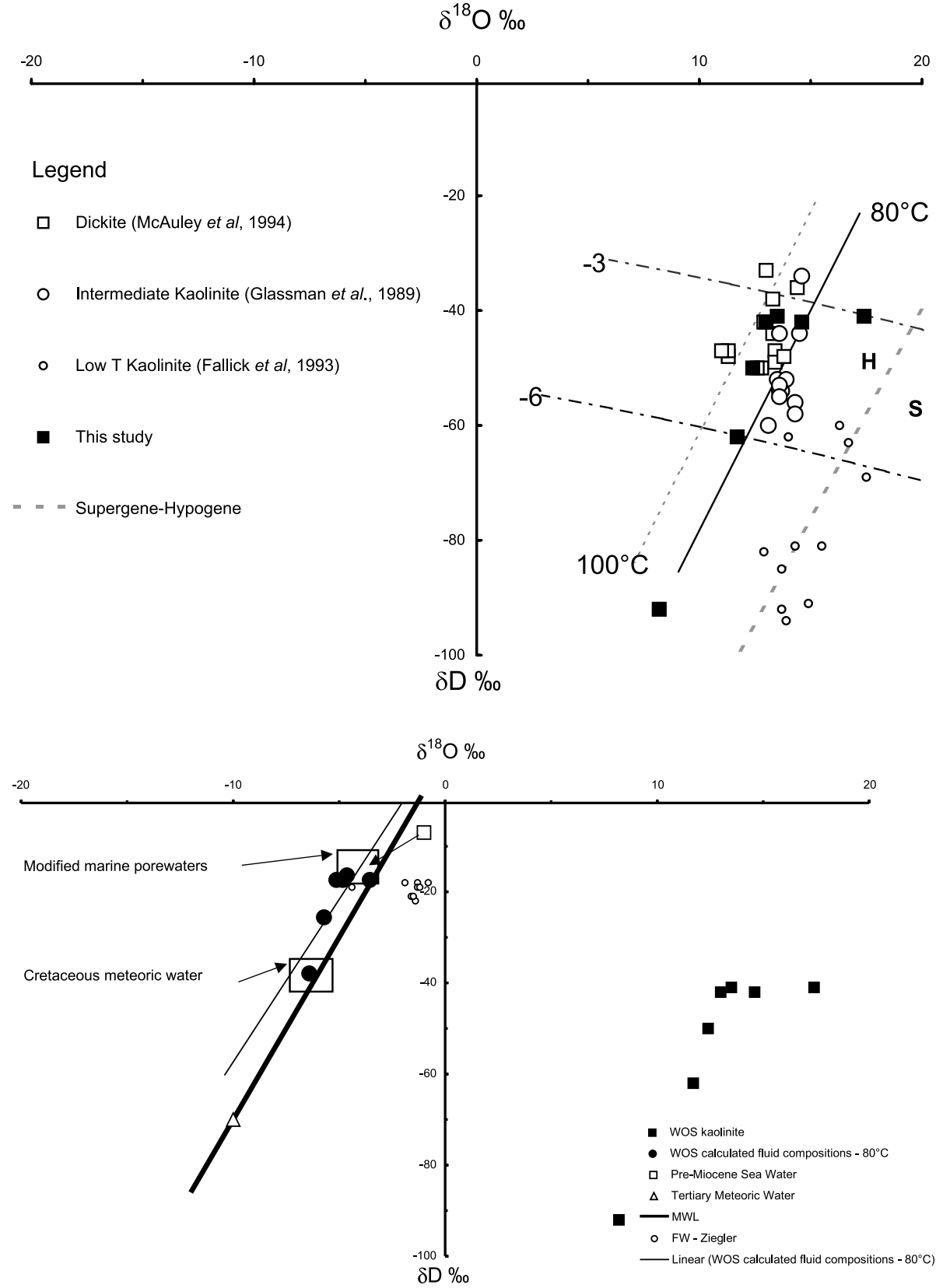

Fig. 9. Isotope cross-plot showing loci of kaolinite compositions in equilibrium with ancient meteoric water of fixed $\delta \mathrm{D}=-3 \%$ and $-6 \%$ between $20^{\circ} \mathrm{C}$ and $200^{\circ} \mathrm{C}$ (dashed lines) and the corresponding loci of compositions in equilibrium with isotopically variable meteoric waters at $80^{\circ} \mathrm{C}$ and $100^{\circ} \mathrm{C}$. Data from Glassman et al. (1989), Fallick et al. (1993) and McAuley et al. (1994).
Fig. 10. Isotopic cross-plot showing fluids in equilibrium with WOS kaolinite. These lie on a linear trend displaced to lower $\delta^{18} \mathrm{O}$ values relative to the present MWL. A two-phase mixing line with end-members represented by modified marine porewaters (upper large box) and Cretaceous (lower box) or Tertiary (triangle) meteoric water could produce the range of calculated equilibrium pore fluid compositions.
Paleocene to Upper Eocene times. In 206/5-2, a hot fluid signature is absent from quartz cements in the upper part of the section, while 214/29-1 shows no evidence for hot fluids in the pre-Tertiary section. In well 214/29-1, thick mudrocks separate Cretaceous and Paleocene sands, acting as a baffle to hydrologic continuity and restricting hot fluid flow to Tertiary aquifers. These results are interpreted as evidence of stratigraphic focusing of hot fluids within aquifer horizons. Cement morphology and zonation, as recorded in SEM-CL, can be used to discriminate Paleocene samples from older (Jurassic and Cretaceous) and younger (Eocene) sandstones. Diagenetic sandstone cements most commonly show oscillatory zoning and are a consequence of increased pressure solution with burial. These cements, which form both gradually and incrementally, are restricted to Jurassic-Cretaceous and Eocene samples and are absent from all but one Paleocene sample. In direct contrast to the processes responsible for the formation of zoned cements, a silica-saturated hot fluid will precipitate silica relatively rapidly when it cools. Rapid precipitation will produce cements that are unzoned (since insufficient time is available to generate growth front concentration gradients). In the case of WOS samples, this has occurred only in Paleoceneaged samples. No evidence for unzoned quartz cements was noted in any pre-Paleocene or Eocene samples (although the shallowest samples studied contained very little cement). Literature examples of unzoned quartz cements are relatively rare, due to the episodic nature of palaeo-porewater migration in response to burial. The restriction of unzoned cements as a hot fluid indicator to a certain stratigraphic level (in this case Paleocene) is again consistent with lateral focusing of hot fluids. Stable isotope data suggest that these fluids are most likely a mixture of ancient meteoric water (Mesozoic-Tertiary) and marine porewaters modified by interaction with volcanic material. Kaolinites equilibrated at temperatures of around $80^{\circ} \mathrm{C}$ 
to $100^{\circ} \mathrm{C}$, and fracture-fill material show intermediate kaolinite morphologies and illite intergrowths consistent with hot fluid interaction.

These results have several implications for the development of sandbodies and source rocks in basin settings that have experienced hot fluid migration. Palaeofluid temperatures of over $200^{\circ} \mathrm{C}$ have been noted, which have the potential to impact the quality of reservoired hydrocarbons (e.g. thermal degradation). As rapid movements of fluid pulses may be required to prevent cooling if migration distances are significant, it could be argued that these pulses have had little effect on maturation or thermal breakdown. These results, however, indicate that hot fluid flow occurred over a relatively long time period (Paleocene to upper Eocene) and, thus, thermal impacts on hydrocarbon quality might be predicted. Further work, to determine the effects on reservoired hydrocarbons is, therefore, important, especially in light of the high temperature oil inclusions in 206/5-2 (and noted previously in 204/19-1) which indicate that the hot fluid pulse involved oil migration.

\section{REFERENCES}

Allègre, C.J., Provost, A. \& Jaupart, C. 1981. Oscillatory zoning: a pathological case of crystal growth. Nature, 294, 223-228.

Allen, P.A. \& Mange-Rajetsky, M.A. 1992. Devonian-Carboniferous sedimentary evolution of the area, offshore north-western UK: impact of changing provenance. Marine and Petroleum Geology, 9, 29-52.

Bailey, N.J.L., Walko, P. \& Sauer, M.J. 1987. Geochemistry and source rock potential of the west of Shetlands. In: Brooks, J. \& Glennie, K.W. (eds) Petroleum Geology of North West Europe. Graham \& Trotman, London, 711-721.

Beaufort, D., Cassagnabere, A., Petit, S., Lanson, B., Berger, G., Lacharpagne, J.C. \& Johansen, H. 1998. Kaolinite-to-dickite reaction in sandstone reservoirs. Clay Minerals, 33(2), 297-316.

Bigeleisen, J., Perlman, M.L. \& Prosser, H.C. 1952. Conversion of hydrogenic materials to hydrogen isotopic analysis. Analytical Chemistry, 24, 1356-1357.

Bjørkum, P.A. \& Nadeau, P.H. 1998. Temperature controlled porosity/ permeability reduction, fluid migration, and petroleum exploration in sedimentary basins. Australian Petroleum Exploration Association Journal, 38, 453-465.

Bodnar, R.J. 1993. Revised equation and table for determining the freezing point depression of $\mathrm{H}_{2} \mathrm{O}-\mathrm{NaCl}$ solutions. Geochimica et Cosmocbimica Acta, 57, 683-684.

Bolton, E.W., Lasaga, A.C. \& Rye, D.M. 1996. A model for the kinetic control of quartz dissolution and precipitation in porous media flow with spatially variable permeability: Formulation and examples of thermal convection. Journal of Geophysical Research, 101(B/10), 22157-22187.

Brint, J.F. 1989. Isotope diagenesis and palaeofluid movement: Middle Jurassic Brent Sandstones, North Sea. PhD thesis. University of Strathclyde, Glasgow.

Clayton, R. \& Mayeda, T.K. 1963. The use of bromine pentafluoride in the extraction of oxygen from oxides and silicates for isotopic analysis. Geochimica et Cosmochimica Acta, 27, 43-52.

Clift, P.D. 1999. The thermal impact of Palaeocene magmatic underplating in the Faeroe-Shetland-Rockall region. In: Fleet, A.J. \& Boldy, S.A.R. (eds) Petroleum Geology of Northwest Europe: Proceedings of the 5 th Conference. Geological Society, London, 585-594.

Dean, K., McLachlan, K. \& Chambers, A. 1999. Rifting and the development of the Faeroe-Shetland Basin. In: Fleet, A.J. \& Boldy, S.A.R. (eds) Petroleum Geology of Northwest Europe: Proceedings of the $5^{\text {th }}$ Conference. Geological Society, London, 533-544.

Fallick, A.E., Macaulay, C. \& Haszeldine, R.S. 1993. Implications of linearly correlated oxygen and hydrogen compositions for kaolinite and illite in the Magnus Sandstone, North Sea. Clays and Clay Minerals, 41(2), 184-190.

Glassman, J.R., Lundegard, P.D., Clark, P.A., Penn, B.K. \& Collins, I.D. 1989. Geochemical evidence for the history of diagenesis and fluid migration; Brent Sandstone, Heather Field, North Sea. Clay Minerals, 24, 255-284.

Green, P.F., Duddy, I.R., Hegarty, K.A. \& Bray, R.J. 1999. Early Tertiary heat flow along the UK Atlantic margin and adjacent areas. In: Fleet, A.J. \& Boldy, S.A.R. (eds) Petroleum Geology of Northwest Europe: Proceedings of the 5th Conference. Geological Society, London, 349-358.

Hamilton, P.J., Fallick, A.E., McIntyre, R.M. \& Elliot, S. 1987. Isotopic tracing of provenance and diagenesis of lower Brent Group sands, North Sea. In: Brooks, J. \& Glennie, K.W. (eds) Petroleum Geology of North West Europe. Graham \& Trotman, London, 939-949.
Hogg, A., Sellier, E. \& Jourdan, A. 1992. Cathodoluminescence of quartz cements in Brent Group sandstones, Alwyn South, UK North Sea. In: Morton, A.C., Haszeldine, R.S., Giles, M.R. \& Brown, S. (eds) Geology of the Brent Group. Geological Society, London, Special Publications, 61, 421-440.

Holmes, A.J., Griffith, C.E. \& Scotchman, I.C. 1999. The Jurassic petroleum system of the West of Britain Atlantic margin - an integration of tectonics, geochemistry and basin modelling. In: Fleet, A.J. \& Boldy, S.A.R. (eds) Petroleum Geology of Northwest Europe: Proceedings of the 5 th Conference. Geological Society, London, 1351-1366.

Holten, T., Jamtveit, B. \& Meakin, P. 2000. Noise and oscillatory zoning of minerals. Geochimica et Cosmochimica Acta, 64(11), 1893-1904.

Lambert, S.J. \& Epstein, S. 1980. Stable isotope investigations of an active geothermal system in Valles Caldera, Jemez Mountains, New Mexico. Journal of Volcanic and Geothermal Research, 8, 111-129.

Lamers, E. \& Carmichael, S.M.M. 1999. The Palaeocene deepwater sandstone play West of Shetland. In: Fleet, A.J. \& Boldy, S.A.R. (eds) Petroleum Geology of Northwest Europe: Proceedings of the 5th Conference. Geological Society, London, 645-659.

Lanson, B., Beaufort, D., Berger, G., Baradat, J. \& Lacharpagne, J.C. 1996. Illitization of diagenetic kaolinite-to-dickite conversion series: late-stage diagenesis of the Lower Permian Rotliegend Sandstone reservoir, offshore of the Netherlands. Journal of Sedimentary Research Section A, 66(3), 501-518.

Lawrence, J.R. \& Gieskes, J.M. 1981. Constraints on water transport and alteration in the oceanic crust from the isotopic composition of pore water. Journal of Geophysical Research, 86(NB9), 7924-7934.

Longstaffe, F.J. \& Ayalon, A. 1990. Hydrogen-isotope geochemistry of diagenetic clay minerals from Cretaceous sandstones, Alberta, Canada: evidence for exchange. Applied Geochemistry, 5, 657-668.

Lyon, I.C., Burley, S.D., McKeever, P.J., Saxton, J.M. \& Macaulay, C. 2000. Oxygen isotope analysis of authigenic quartz in sandstones: a comparison of ion microprobe and conventional analytical techniques. In: Morad, S. (ed.) Quarty Cementation in Sandstones. International Association of Sedimentologists Special Publication, 29, 299-316.

McAuley, G.E., Burley, S.D., Fallick, A.E. \& Kusznir, N.J. 1994. Palaeohydrodynamic fluid flow regimes during diagenesis of the Brent Group in the Hutton-NW Hutton reservoirs: constraints from oxygen isotope studies of authigenic kaolin and reverse flexural modelling. Clay Minerals, 29, 609-626.

Milliken, K.L. \& Laubach, S.E. 2000. Brittle deformation in sandstone diagenesis as revealed by scanned cathodoluminescence imaging with application to characterisation of fractured reservoirs. In: Pagel, M., Barbin, V, Blanc, P \& Ohnenstetter, D (eds) Cathodoluminescence in Geosciences. Springer Verlag, Heidelberg, 225-243.

Nadin, P.A., Kusznir, N.J. \& Cheadle, M.J. 1997. Early Tertiary plume uplift of the North Sea and Faeroe-Shetland Basins. Earth and Planetary Science Letters, 148(1/2), 109-128.

Naylor, P.H., Bell, B.R., Jolley, D.W., Durnall, P. \& Fredsted, R. 1999. Palaeogene magmatism in the Faeroe-Shetland Basin: influences on uplift history and sedimentation. In: Fleet, A.J. \& Boldy, S.A.R. (eds) Petroleum Geology of Northwest Europe: Proceedings of the 5 th Conference. Geological Society, London, 545-558.

Osborne, M., Haszeldine, R.S. \& Fallick, A.E. 1994. Variation in kaolinite morphology with growth temperature in isotopically mixed pore-fluids. Clay Minerals, 29, 591-608.

Parnell, J., Carey, P.F., Green, P. \& Duncan, W. 1999. Hydrocarbon migration history, West of Shetland; integrated fluid inclusion and fission track studies. In: Fleet, A.J. \& Boldy, S.A.R. (eds) Petroleum Geology of Northwest Europe: Proceedings of the 5 th Conference. Geological Society, London, 613-625.

Parnell, J., Middleton, D., Bordas-Le Floch, N. \& Watt, G.R. 2001. Hot fluids in passive margin basins. In: Earth System Processes. A Global Meeting Presented by the Geological Society of America and the Geological Society of London, 24-28 June 2001, Edinburgh.

Savin, S.M. \& Lee, M. 1988. Isotopic studies of phyllosilicates. In: Bailey, S.W. (ed.) Hydrous Phyllosilicates (exclusive of micas). Reviews in Mineralogy, 19. Mineralogical Society of America, Washington, 189-223.

Sheppard, S.M.F. 1986. Characterisation and isotopic variations in natural waters. In: Valley, J. W., Taylor, Jr, H. P. \& O’Neil, J. R. (eds) Stable isotopes in bigh temperature geological processes. Reviews in Mineralogy, 16, Mineralogical Society of America, Washington, 165-183.

Sheppard, S.M.F. \& Gilg, H.A. 1996. Stable isotope geochemistry of clay minerals. Clay Minerals, 31(1), 1-24.

Shore, M. \& Fowler, A.D. 1996. Oscillatory zoning in minerals: a common phenomenon. Canadian Mineralogist, 34, 1111-1126.

Stoker, M.S., Hitchin, K. \& Graham, C.C. 1993. United Kingdom offshore regional report: the geology of the Hebrides and West Shetland shelves, and adjacent deep water areas. British Geological Survey, HMSO, London.

Thrasher, J. 1992. Thermal effect of the Tertiary Cuillins Intrusive Complex in the Jurassic of the Hebrides: an organic geochemical study. In: Parnell, J. (ed.) Basins on the Atlantic Seaboard: Petroleum Geology, Sedimentology and Basin Evolution. Geological Society, London, Special Publications, 62, 35-49. 
Turner, J.D. \& Scrutton, R.A. 1993. Subsidence patterns in western margin basins: evidence from the Faeroe-Shetland Basin. In: Parker, J.R. (ed.) Petroleum Geology of Northwest Europe: Proceedings of the 4th Conference. Geological Society, London, 975-983.

Waldehaug, O. 1994. Precipitation rates for quartz cement in sandstones determined by fluid inclusion microthermometry and temperature-history modelling. Journal of Sedimentary Research, A64/2, 324-333.
Watt, G.R., Wright, P., Galloway, S. \& McLean, C. 1997. Cathodoluminescence and trace element zoning in quartz phenocrysts and xenocrysts. Geochimica et Cosmochimica Acta, 61, 4337-4348.

Ziegler, K., Coleman, M.L. \& Howarth, R.J. 2001. Palaeohydrodynamics of fluids in the Brent Group (Oseberg Field, Norwegian North Sea) from chemical and isotopic compositions of formation waters. Applied Geochemistry, 16, 609-632.

Received 7 January 2003; revised typescript accepted 23 April 2003. 